\title{
The Nogo-66 Receptor Homolog NgR2 Is a Sialic Acid-Dependent Receptor Selective for Myelin-Associated Glycoprotein
}

\author{
Karthik Venkatesh, ${ }^{1}$ Onanong Chivatakarn, ${ }^{1}$ Hakjoo Lee, ${ }^{1}$ Pushkar S. Joshi, ${ }^{1}$ David B. Kantor, ${ }^{2}$ Barbara A. Newman, ${ }^{3}$ \\ Rose Mage, ${ }^{3}$ Christoph Rader, ${ }^{4}$ and Roman J. Giger ${ }^{1}$ \\ ${ }^{1}$ Center for Aging and Developmental Biology, University of Rochester School of Medicine and Dentistry, Rochester, New York 14642, ${ }^{2}$ Department of \\ Neuroscience, The Johns Hopkins University School of Medicine, Baltimore, Maryland 21205, ${ }^{3}$ Laboratory of Immunology, National Institute of Allergy and \\ Infectious Diseases, National Institutes of Health, Bethesda, Maryland 20892-1892, and ${ }^{4}$ Experimental Transplantation and Immunology Branch, Center for Cancer \\ Research, National Cancer Institute, National Institutes of Health, Bethesda, Maryland 20892-1907
}

The Nogo-66 receptor (NgR1) is a promiscuous receptor for the myelin inhibitory proteins Nogo/Nogo-66, myelin-associated glycoprotein (MAG), and oligodendrocyte myelin glycoprotein (OMgp). NgR1, an axonal glycoprotein, is the founding member of a protein family composed of the structurally related molecules NgR1, NgR2, and NgR3. Here we show that NgR2 is a novel receptor for MAG and acts selectively to mediate MAG inhibitory responses. MAG binds NgR2 directly and with greater affinity than NgR1. In neurons NgR1 and $\mathrm{NgR} 2$ support MAG binding in a sialic acid-dependent Vibrio cholerae neuraminidase-sensitive manner. Forced expression of NgR2 is sufficient to impart MAG inhibition to neonatal sensory neurons. Soluble NgR2 has MAG antagonistic capacity and promotes neuronal growth on MAG and CNS myelin substrate in vitro. Structural studies have revealed that the NgR2 leucine-rich repeat cluster and the NgR2 "unique" domain are necessary for high-affinity MAG binding. Consistent with its role as a neuronal MAG receptor, NgR2 is an axonassociated glycoprotein. In postnatal brain NgR1 and NgR2 are strongly enriched in Triton X-100-insoluble lipid rafts. Neural expression studies of NgR1 and NgR2 have revealed broad and overlapping, yet distinct, distribution in the mature CNS. Taken together, our studies identify NgRs as a family of receptors (or components of receptors) for myelin inhibitors and provide insights into how interactions between MAG and members of the Nogo receptor family function to coordinate myelin inhibitory responses.

Key words: neuron; axon; neurite outgrowth; myelin; MAG; Nogo receptor; ganglioside

\section{Introduction}

In higher vertebrates, including humans, the regenerative capacity of injured CNS neurons is extremely limited. Multiple lines of evidence point to CNS myelin as a major source for inhibitory proteins that impair axonal regeneration (Schwab et al., 1993; McGee and Strittmatter, 2003). One of the best characterized inhibitors of axonal growth is myelin-associated glycoprotein (MAG) (Filbin, 2003). In vitro, MAG regulates neurite outgrowth in an age-dependent manner. MAG promotes growth of many types of embryonic and neonate neurons and, at more mature stages, strongly inhibits growth (Johnson et al., 1989; McKer-

Received Aug. 29, 2004; revised Nov. 30, 2004; accepted Dec. 2, 2004.

This work was supported by the New York State Spinal Cord Injury Research Program (R.J.G. and C.R.), the Ellison Medical Foundation, National Alliance for Research on Schizophrenia and Depression, the Alexandrine and Alexander Sinsheimer Foundation, National Institute of Neurological Disorders and Stroke Grant NS047333 (R.J.G.), and National Institutes of Health Training Grant T32 NS07489 (K.V.). We thank J. Lee-Osbourne, D. Welch, M. Lefort, and T. Wychowski for excellent technical assistance; Z. Ali for anti-NgR1 and anti-NgR2 tissue Western blots; A. Kolodkin for NgR1 and NgR2 expression plasmids; R. Schnaar for MAG-Fc, CHO-MAG, and CHO-R2 cell lines; M. Filbin for MAG-Fc; Z. He for AP-OMgp; H. Federoff for Ad-RFP; and M. Lefort for help with figures.

Correspondence should be addressed to Roman J. Giger, Graduate Program in Neuroscience, Center for Aging and Developmental Biology, University of Rochester School of Medicine and Dentistry, 601 Elmwood Avenue, Rochester, NY 14642. E-mail: Roman_Giger@URMC.Rochester.edu.

D01:10.1523/JNEUROSCI.4464-04.2005

Copyright $\odot 2005$ Society for Neuroscience $\quad$ 0270-6474/05/250808-15\$15.00/0 racher et al., 1994; Mukhopadhyay et al., 1994; Hasegawa et al., 2004). Loss of MAG is not sufficient to improve regenerative growth in spinal cord-injured mice (Bartsch et al., 1995), but there is good evidence that MAG has growth inhibitory activity toward regenerating neurons in vivo (Schafer et al., 1996; Sicotte et al., 2003).

MAG, a sialic acid-binding Ig-like lectin (Siglec), binds preferentially to carbohydrates bearing terminal $\alpha 2,3$-linked sialic acids (Crocker and Varki, 2001; Vyas and Schnaar, 2001). MAG binds to the neuronal cell surface and inhibits growth in a sialic acid-dependent Vibrio cholerae neuraminidase-sensitive (VCNsensitive) manner (Kelm et al., 1994; DeBellard et al., 1996). Select gangliosides, including GT1b and GD1a, support sialic aciddependent MAG binding and play an important role in MAG inhibitory neuronal responses (Yang et al., 1996; Vinson et al., 2001; Vyas et al., 2002). However, the mechanisms of how MAG binding to gangliosides triggers intracellular signaling events, such as activation of RhoA, are not well understood. The sialic acid dependence of MAG inhibition was challenged by the recent identification of the Nogo-66 receptor (NgR1) as a high-affinity MAG receptor that supports binding in a sialic acid-independent manner (Domeniconi et al., 2002; Liu et al., 2002). The MAG$\mathrm{NgR} 1$ interaction is functionally significant; anti-NgR1 antibod- 
ies block MAG inhibition (Domeniconi et al., 2002; Li et al., 2004), and ectopic expression of NgR1 in embryonic chick dorsal root ganglion (DRG) neurons is sufficient to confer MAG responsiveness (Liu et al., 2002).

Based on initial observations that neurons from $p 75$ mutant mice are no longer inhibited by MAG (Yamashita et al., 2002), two subsequent studies identified the pan-neurotrophin receptor p75 as the signal-transducing component in a NgR1/p75 receptor complex (K. C. Wang et al., 2002b; Wong et al., 2002). In addition, Lingo-1/Lern-1, a nervous system-specific type-I membrane protein (Carim-Todd et al., 2003), is an essential component of the $\mathrm{NgR} 1 / \mathrm{p} 75$ receptor system in vitro (Mi et al., 2004). In spinal cord-injured mice, however, depletion of functional p75 is not sufficient to improve the regenerative growth of descending corticospinal or ascending sensory neurons (Song et al., 2004). This implies the existence of p75-independent mechanisms sufficient to bring about inhibition in vivo.

The recent identification of NgR2 and NgR3, two NgR1related proteins, raises the question as to whether these molecules, similar to NgR1, play a role in myelin inhibition. Here we report the identification of NgR2 as a high-affinity and sialic acid-dependent receptor for MAG.

\section{Materials and Methods}

Reagents. The following materials were used: OptiMEM, DMEM, Neurobasal medium, L15, B27 supplement, fetal bovine serum (FBS), dialyzed FBS, HBSS, Pen/Strep, G418, and glutamine (Invitrogen, San Diego, CA); MAG-Fc (M. Filbin, Hunter College, City University of New York, New York, NY; R. Schnaar, Johns Hopkins University, Baltimore, $\mathrm{MD}$; and R \& D Systems, Minneapolis, MN); CHO-MAG and CHO-R2 cells (R. Schnaar); oligodendrocyte myelin glycoprotein (OMgp-AP; Z. $\mathrm{He}$, Children's Hospital, Harvard Medical School, Boston, MA); Siglec 3-Fc and NgR-Fc (R \& D Systems); Ad-RFP (H. Federoff, University of Rochester, Rochester, NY); anti-caveolin (Upstate Biotechnology, Lake Placid, NY); anti-human Fc-AP-conjugated, anti-rabbit IgG-APconjugated, class III $\beta$-tubulin antibody (TuJ1; Promega, Madison, WI); anti-MAG monoclonal antibody 513 (mAb 513) and anti-p75 clone 192 (Chemicon, Temecula, CA); Alexa red anti-mouse IgG and Alexa green anti-rabbit IgG (Molecular Probes, Eugene, OR); anti-green fluorescent protein (anti-GFP; Rockland Immunochemicals, Gilbertsville, PA); anti-AP (American Research Products, Belmont, MA); anti-myc (9B11; Cell Signaling Technology, Beverly, MA); spin columns (Vivascience, Edgewood, NY); VCN, RNA polymerases, Tth-DNA polymerase, and DIG-RNA labeling kit (Roche Molecular Biochemicals, Indianapolis, IN); isopropyl $\beta$-D-thiogalactoside (IPTG), Lipofectamine 2000, and pTrcHis (Invitrogen); Percoll (MP Biomedicals, Irvine, CA); mammalian tissue protease inhibitor mixture, insulin, transferrin, NBT/BCIP tablets, T3/T4, progesterone, MES, and selenium (Sigma, St. Louis, MO); restriction enzymes (New England Biolabs, Beverly, MA); Protein G Plus/Protein A-agarose beads (Oncogene, San Diego, CA); BCA kit (Pierce, Rockford, IL); HRP/ECL detection system (Amersham Biosciences, Piscataway, NJ); and ABC system (Vector Laboratories, Burlingame, CA).

Identification of NgR2 and NgR3. tBLAST database searches with fulllength NgR1 revealed several human and mouse expressed sequence tags (ESTs) with identities between 41 and $63 \%$ to NgR1. EST (Gi:4274260) was used to generate primers for RT-PCR. Primers 207-forward GCCATCCCGGAGGGCATCCC and 207-back ACACTTATAGAGGTAGAGGGCGTG amplified a $267 \mathrm{bp}$ PCR product from embryonic day 15 (E15) rat brain first-strand cDNA. The EST clone IMAGE:1926673 (GenBank accession number AI346757) was ordered from Genome Systems (St. Louis, MO). Both cDNA fragments were labeled with ${ }^{32} \mathrm{P}$ dCTP and used to screen an E15 rat spinal cord/DRG cDNA library (Kolodkin et al., 1997). Several clones were identified and endsequenced. Of these, clones 207-17 (2.1 kb) and 208-56 (1.9 kb) contained the largest inserts and were sequenced on both strands, revealing open reading frames of the NgR1-like polypeptides NgR2 and NgR3.
Generation of immune sera. Rabbits were immunized with 6-his-tagged fusion proteins of each of the NgR family members. Fusion proteins include the less-conserved C-terminal sequences: the LRRCT and the "unique" domains of NgR1 (amino acids 278-473), NgR2 (amino acids 279-420), and NgR3 (amino acids 274-445). Fusion proteins were expressed from the pTrcHis vector after induction with IPTG (1 mM) of Escherichia coli cultures at an $\mathrm{OD}_{600}$ of 0.8 . The three 6-his-tagged fusion proteins were purified over a Ni-NTA column and used for rabbit immunization (Popkov et al., 2003).

Generation of ligand and receptor constructs. Human placental alkaline phosphatase-tagged (AP-tagged) fusion proteins were constructed by standard PCR cloning techniques, using the Tth-DNA polymerase and assembled in the pcDNA-AP vector after digestion with BglII and EcoR1 (Giger et al., 1998). AP-Nogo-66 (Fournier et al., 2001), AP-NiG (Niederost et al., 2002), OMgp-AP (Wang et al., 2002a), AP-Fc (Giger et al., 1998), AP-MAG (Liu et al., 2002), AP-sNgR1 ( $\mathrm{Ala}^{24}-\mathrm{Glu}^{445}$ ), AP-sNgR2 $\left(\mathrm{Ser}^{30}-\mathrm{Ser}^{396}\right)$, and AP-sNgR3 $\left(\mathrm{Ser}^{22}-\mathrm{Val}^{420}\right.$ ) were expressed in Lipofectamine 2000-transfected HEK293T cells and harvested from conditioned cell culture supernatant in OptiMEM. Expression of fusion proteins was confirmed by immunoblotting with anti-AP serum. For ligand quantification the AP activity was determined enzymatically $\left(\mathrm{OD}_{405}\right)$. If necessary, ligands were concentrated by using spin columns with a molecular weight cutoff of $10 \mathrm{kDa}$. Receptor constructs included N-terminally myc-tagged NgR1 (Pro ${ }^{26}-\mathrm{Cys}^{473}$ ), myc-NgR2 $\left(\mathrm{Ser}^{30}-\mathrm{Leu}^{420}\right)$, and mycNgR3 $\left(\right.$ Gly $^{24}$-Arg ${ }^{445}$ ) assembled in the expression vector pMT21 (Kolodkin et al., 1997). Also included were chimera $\operatorname{NgR} 2^{\mathrm{LRR}}\left(\mathrm{Met}^{1}-\mathrm{Pro}^{313}\right) /$ NgR1 ${ }^{\text {unique }}\left(\mathrm{Gly}^{314}-\mathrm{Cys}^{473}\right)$ fused by SpeI, introducing $\mathrm{Thr}^{314}$ and Ser ${ }^{315}$; $\mathrm{NgR} 1{ }^{\mathrm{LRR}}\left(\mathrm{Met}^{1}-\mathrm{Val}^{311}\right) / \mathrm{NgR} 2^{\text {unique }}\left(\mathrm{Pro}^{315}{ }^{31} \mathrm{Lys}^{420}\right.$ ) fused by SpeI, introducing $\mathrm{Thr}^{312}$ and $\mathrm{Ser}^{313}$; NgR3 ${ }^{\mathrm{LRR}}\left(\mathrm{Met}^{1}-\mathrm{Pro}^{307}\right) / \mathrm{NgR} 2^{\text {unique }}{ }^{3}$ Pro $^{315}$

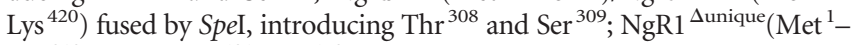
Pro $\left.^{313}\right) / \mathrm{NgR} 1\left(\right.$ Leu $^{431}-\mathrm{Cys}^{473}$ ) fused by SpeI/XbaI, introducing Thr and Arg at the fusion site; $\mathrm{NgR} 2^{\text {uunique }}\left(\mathrm{Met}^{1}-\mathrm{Val}^{311}\right) / \mathrm{NgR} 1\left(\mathrm{Leu}^{431}-\mathrm{Cys}{ }^{473}\right)$ fused by SpeI/XbaI. For adenoviral vectors the full-length NgR1 and NgR2 were cloned into pAdTrack-CMV and recombined with pAdEasy-1 in E. coli. Recombinant virus was produced and amplified in HEK293 cells and purified by double $\mathrm{CsCl}$ banding as described previously (Giger et al., 1997).

Ligand-receptor binding studies. Receptor constructs were expressed transiently in COS-7 cells in 24-well plates coated with poly-D-lysine (PDL; $50 \mu \mathrm{g} / \mathrm{ml}$ ), using Lipofectamine 2000. To assess cell surface expression of transiently expressed receptor constructs, we stained some wells with anti-NgR1 (1:1000), anti-NgR2 (1:1000), or anti-NgR3 (1: 200) under nonpermeabilizing conditions. At $24 \mathrm{~h}$ after transfection the cells were rinsed and incubated for $75 \mathrm{~min}$ at ambient temperature with the following (in nM): 10 AP-Nogo-66, 10 OMgp-AP, 20 AP-NiG, 20 AP-Fc, 33 AP-MAG, 17 MAG-Fc, 30 Siglec 3-Fc, or 8 anti-human Fc-APconjugated antibody. Before binding, MAG-Fc and Siglec 3-Fc were oligomerized by preincubation with anti-human Fc conjugated to $\mathrm{AP}(2: 1)$. Of note, dimeric MAG-Fc (not preclustered by preincubation with antihuman Fc-AP) still binds to NgR2 in COS-7 cells (see Fig. 2 B). Consistent with previous studies, however, the strength of binding is increased if MAG-Fc is oligomerized (Strenge et al., 1999). For antibody blocking of MAG binding the MAG-Fc was preincubated for $1 \mathrm{~h}$ with anti-MAG mAb $513(10 \mu \mathrm{g} / \mathrm{ml})$ or anti-p75 mAb $192(10 \mu \mathrm{g} / \mathrm{ml})$ in OptiMEM. Unbound ligand was removed by several rinses in HBHA $(1 \times$ HBS supplemented with $20 \mathrm{~mm}$ HEPES, pH 7.0, 0.05\% BSA, 0.5\% $\mathrm{NaN}_{3}$ ). Cells were fixed in $60 \%$ acetone, $1 \%$ formaldehyde, and 20 mM HEPES, pH 7.0, rinsed in $\mathrm{HBHA}$, and heated at $65^{\circ} \mathrm{C}$ in $\mathrm{HBS}$ for $60 \mathrm{~min}$. To monitor bound ligand, we developed plates with NBT/BCIP substrate; the color reaction was stopped by two rinses in PBS. For quantification of ligand binding the cells were processed as described above; after ligand incubation the cells were rinsed in HBHA and lysed in $20 \mathrm{~mm}$ Tris, $\mathrm{pH} 8.0,0.1 \%$ Triton X-100. The lysates were incubated at $65^{\circ} \mathrm{C}$ for $60 \mathrm{~min}$ and spun at $10,000 \times g$ for $5 \mathrm{~min}$. The relative AP activity in supernatants was normalized to cell surface receptor expression, using anti-myc (1:1000), anti-NgR1 (1:1000), anti-NgR2 (1:1000), or anti-NgR3 (1:200) antibodies, as described previously (Giger et al., 1998). Scatchard plot analysis of the MAG-Fc binding to NgR2-expressing COS-7 cells was performed analogous to a previous study (Kolodkin et al., 1997). For binding of MAG-Fc and AP-Nogo-66 to dissociated DRGs 25,000 cells/well were 
A

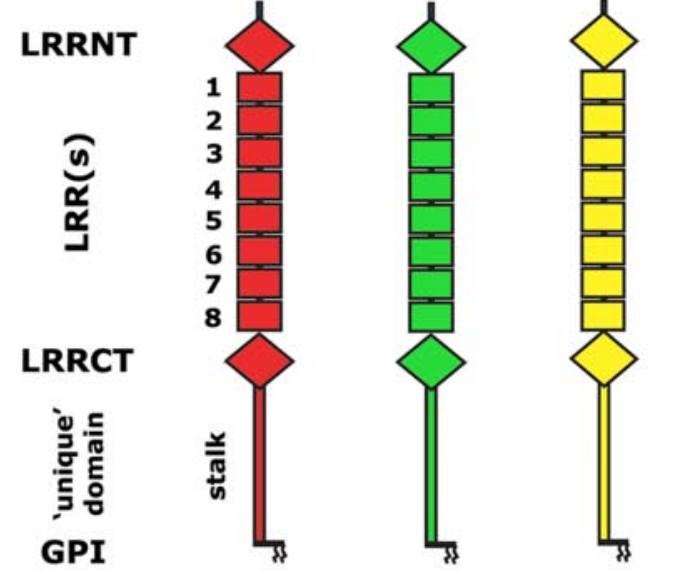

B
NgR1
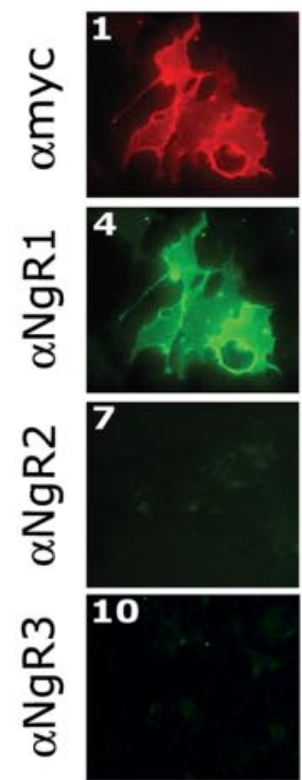

NgR2
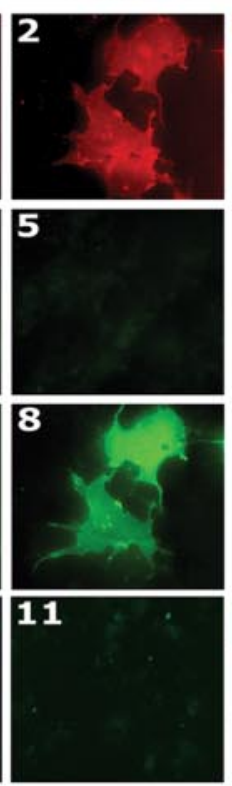

C
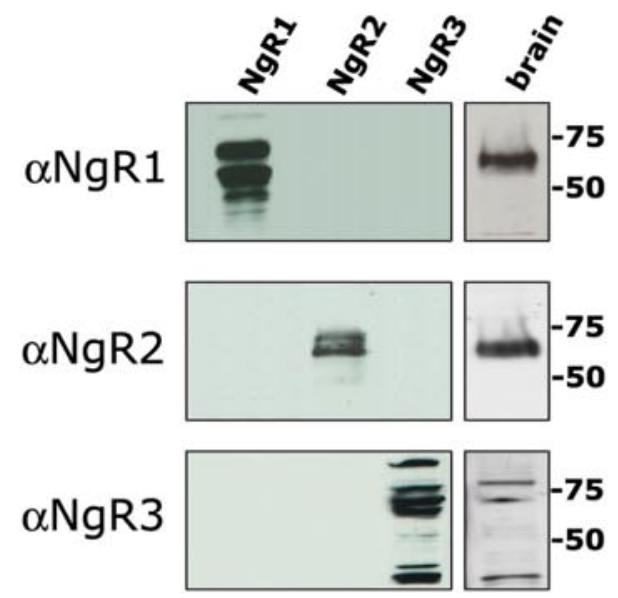

Figure 1. Characterization of antibodies raised against Nogo receptor family members. $A$, Domain alignment of the Nogo receptor family members $\mathrm{NgR} 1$ (473 amino acid residues), NgR2 (420 amino acid residues), and NgR3 (445 amino acid residues). Nogo receptors are composed of eight canonical leucine-rich repeats (LRR1-LRR8) flanked by cysteine-rich LRRNT and LRRCT plated in four-well plates on $100 \mu \mathrm{g} / \mathrm{ml} \mathrm{PDL}$ and cultured in Sato ${ }^{+}$ medium [ $20 \mathrm{~nm}$ progesterone, $30 \mathrm{~nm}$ selenium, $5 \mu \mathrm{g} / \mathrm{ml}$ insulin, $4 \mathrm{mg} / \mathrm{ml}$ BSA, $0.1 \mu \mathrm{g} / \mathrm{ml}$ L-thyroxine, $0.08 \mu \mathrm{g} / \mathrm{ml}$ triiodo-thyronine; for neonatal (postnatal day 1-2 [P1-P2]) DRGs $15 \mathrm{ng} / \mathrm{ml} \mathrm{NGF}$ was added]. After $48 \mathrm{~h}$ the DRGs were infected with adenoviral NgR1 (Ad-NgR1) or Ad-NgR2 (multiplicity of infection, $\sim 100$ ). Before ligand-binding studies the viral transduction of DRGs was confirmed by live monitoring of GFP expression. Then neuronal cultures were rinsed and incubated in OptiMEM or OptiMEM with VCN $(20 \mathrm{mU} / \mathrm{ml})$ at $37^{\circ} \mathrm{C}$ for $1 \mathrm{~h}$. Ligand binding was performed as described above.

Histochemical procedures. For in situ hybridization cryosections of postnatal rat tissue were incubated with digoxigenin-labeled (DIG-11UTP; Roche Molecular Biochemicals ) cRNA probes generated by in vitro transcription, using the T3, T7, or SP6 RNA-polymerase. Probes for $N g R 1$ and $N g R 2$ were transcribed from cDNA fragments encoding the less-conserved C-terminal sequences and included a $\mathrm{NgR} 1$ ( $0.96 \mathrm{~kb}$ fragment in pGEM downstream of codon $\mathrm{Arg}^{279}$ ) linearized with XhoI or $\mathrm{XbaI}$ to generate sense (T7) and antisense (SP6) probes and a NgR2 (1.03 $\mathrm{kb}$ fragment in pBluescript downstream of codon $\mathrm{Arg}^{280}$ ) linearized with $X b a \mathrm{I}$ or EcoR1 to generate sense (T3) and antisense (T7) probes. In addition, a DIG-labeled VIP sense probe was used as a negative control. To enhance tissue penetration, we carbonate-digested cRNA probes at $60^{\circ} \mathrm{C}, \mathrm{pH} \sim 11$, for $45 \mathrm{~min}$, to an average length of 150-250 bases. Hybridization was performed at $60^{\circ} \mathrm{C}$ in $50 \%$ formamide, with a final concentration of $\sim 100-200 \mathrm{ng}$ of DIG probe/ml hybridization solution (Giger et al., 1996).

For immunohistochemistry the eyes of adult rats were flash frozen in dry ice-cooled isopentane and cryosectioned at $20 \mu \mathrm{m}$. Sections were fixed for $10 \mathrm{~min}$ in cooled methanol, followed by several rinses in PBS. Endogenous peroxidases were quenched; sections were blocked in normal goat serum and incubated in primary antibody overnight at $4^{\circ} \mathrm{C}$. Anti-NgR1 (1:1000) and anti-NgR2 (1:1000) were detected with a biotinylated anti-rabbit IgG (1:500) and visualized by using the Nienhanced horseradish peroxidase $\mathrm{ABC}$ system. Sections were dehydrated in a graded series of ethanol and cleared in xylene.

Isolation of lipid rafts and immunoblotting. Brains obtained from P14 rats were homogenized in ice-cold MES-buffered saline containing $0.1 \%$ Triton X-100 and protease inhibitor mixture. The homogenate was passed several times through a 21 -gauge needle, and cellular debris was removed by low speed centrifugation $(3000 \times g$ for $15 \mathrm{~min})$. From the resulting supernatant Triton X-100-insoluble membrane rafts were enriched by flotation in a $5-40 \%$ sucrose gradient for $36 \mathrm{~h}$ at $200,000 \times \mathrm{g}$. Fractions of the gradient were collected $(0.5 \mathrm{ml})$, diluted in PBS, and precipitated at $10,000 \times g$ for $30 \mathrm{~min}$. Pellets were resuspended and subjected to Western blot analysis by using anti-NgR1 (1:2000), antiNgR2 (1:2000), or anti-caveolin (1:1000) antibodies. Fractions containing the highest amounts of $\mathrm{NgR} 1$ and $\mathrm{NgR} 2$ were pooled and incubated in OptiMEM or OptiMEM and VCN $(20 \mathrm{mU} / \mathrm{ml})$ at $37^{\circ} \mathrm{C}$ for $1 \mathrm{~h}$ before Western blot analysis.

Affinity precipitation. COS- 7 cells in $10 \mathrm{~cm}$ culture dishes were infected with Ad-NgR1 or Ad-NgR2 in OptiMEM. After $24 \mathrm{~h}$ the cells were incubated in lysis buffer containing the following (in mM): 20 Tris- $\mathrm{HCl}, \mathrm{pH}$

\footnotetext{
subdomains. The highly conserved $L R R N T+L R R+L R R C T$ domains are connected via a more variable unique domain (stalk) to a GPI anchor for membrane attachment. We raised polyclonal antibodies against the distal part of the LRRCT and the unique domain of each of the three $\mathrm{NgR}$ family members. $B$, Immunocytochemistry (ICC) under nonpermeabilizing conditions of myc-tagged $\mathrm{NgR1}, \mathrm{NgR2}$, and $\mathrm{NgR3}$ in transfected COS-7 cells reveals abundant cell surface localization of $\mathrm{NgR1}(B 1), \mathrm{NgR2}(B 2)$, and NgR3 (B3). Anti-NgR1 (B4), anti-NgR2 (B8), and anti-NgR3 (B12) immune sera strongly and selectively react with their cognate antigens. No cross-reactivity with other $\mathrm{NgR}$ family members is observed. C, Western blotting with anti-NgR1, anti-NgR2, and anti-NgR3 immune sera allows for selective detection of recombinant (COS-7) and endogenously (adult rat brain) expressed receptors. All three $\mathrm{NgR}$ family members are expressed abundantly in the adult brain. Of note, endogenously expressed $\mathrm{NgR} 1$ and $\mathrm{NgR} 2$ are detected as single bands and migrate at an apparent molecular weight of $65 \mathrm{kDa}$. Recombinant $\mathrm{NgR} 1$ and $\mathrm{NgR2}$ occur as multiple variants between 55 and 70 $\mathrm{kDa}$ (Walmsley et al., 2004). Multiple variants are found for recombinant and endogenously expressed NgR3. Scale bar, $20 \mu \mathrm{m}$.
} 
A
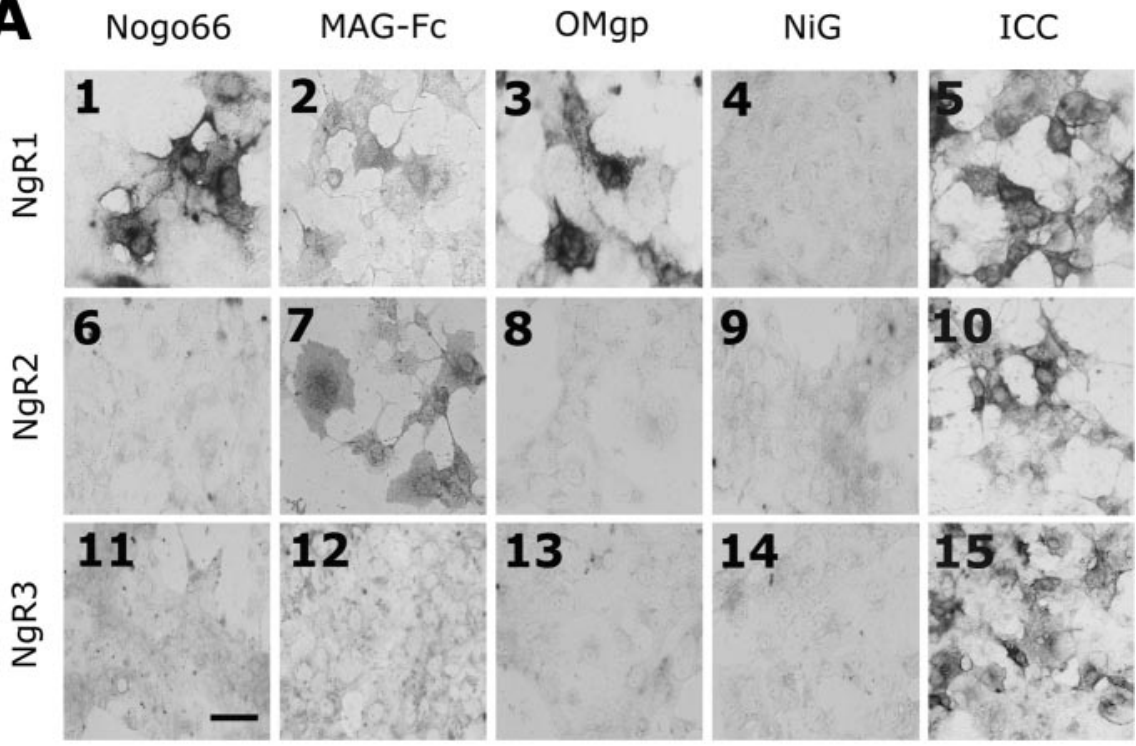

13
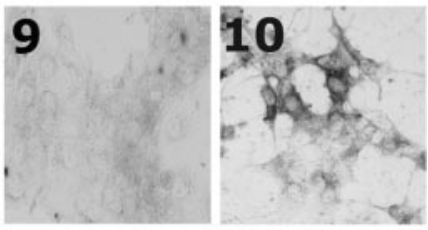

B

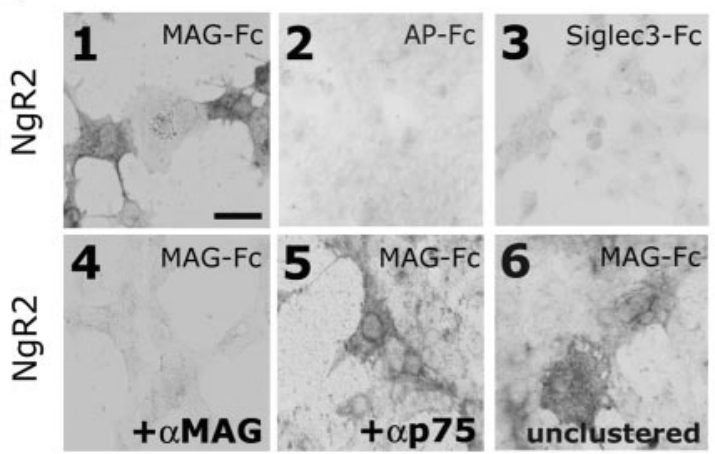

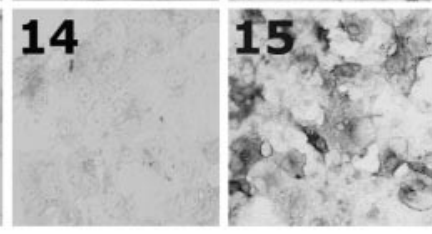

C

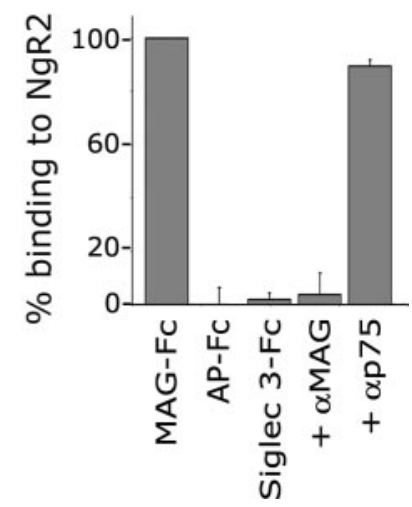

Figure 2. Binding profile of myelin inhibitors to Nogo receptors. $A$, Binding of AP-Nogo-66 $(A 1, A 6, A 11), \operatorname{MAG}-\mathrm{Fc}(A 2, A 7, A 12)$, 0 Mgp-AP $(A 3, A 8, A 13)$, and AP-NiG $(A 4, A 9, A 14)$ to recombinant NgR1, NgR2, and NgR3 transiently expressed in COS-7 cells. Bound MAG-Fc was detected with anti-human Fc conjugated to AP. Immunocytochemistry with anti-NgR1 (A5), anti-NgR2 (A10), and anti-NgR3 (A15) was used to confirm expression of transfected receptor constructs. B, NgR2 supports binding of oligomerized MAG-Fc (B1), but not AP-Fc (B2) or Siglec 3-Fc (B3). Binding of oligomerized MAG-Fc to NgR2 is blocked by anti-MAG 513 (B4), but not by anti-p75 $192 \mathrm{lgG}$ (B5). MAG-Fc that has not been oligomerized with anti-human Fc (unclustered) still binds to $\mathrm{NgR2}$ (B6). C, Quantification of ligand binding in relative AP units. Binding of MAG to NgR2 is equal to $100 \%$. NgR2 does not support AP-Fc or Siglec 3-Fc binding. MAG binding is blocked in the presence of anti-MAG $(10 \mu \mathrm{g} / \mathrm{ml})$, but not anti-p $75(10 \mu \mathrm{g} / \mathrm{ml}) \mathrm{lgG}$. Scale bars: $A, B, 20 \mu \mathrm{m}$.

7.5, $150 \mathrm{NaCl}, 5$ EDTA plus 1\% NP-40 and protease inhibitor mixture. Cell lysates were tumbled overnight at $4^{\circ} \mathrm{C}$ in the presence of MAG-Fc (2 $\mu \mathrm{g})$ or control IgG $(2 \mu \mathrm{g})$ and precipitated with Protein G Plus/Protein A-agarose after incubation at $4^{\circ} \mathrm{C}$ for $2 \mathrm{~h}$. Cell lysates of Ad-NgR2transduced COS-7 cells, AP-Nogo-66 (15 nM), or AP-NiG (20 nM) were incubated with NgR-Fc (2 $\mu \mathrm{g})$ and precipitated with Protein G Plus/ Protein A-agarose after incubation at $4^{\circ} \mathrm{C}$ for $2 \mathrm{~h}$. To assess direct MAG interactions, we preincubated $1 \mathrm{~nm}$ AP-sNgR1, $1 \mathrm{~nm}$ AP-sNgR2, or $1 \mathrm{~nm}$ AP-sNgR3 in OptiMEM with $1 \mu \mathrm{g}$ of MAG-Fc. Precipitated beads were rinsed three times with lysis buffer, and bound proteins were eluted with $2 \times$ SDS sample buffer. Precipitates were analyzed by immunoblotting, using anti-NgR1, anti-NgR2, or anti-AP antisera.

For affinity precipitation studies with neurons the cultures of P1-P2 DRGs were transfected with Ad-NgR1 and Ad-NgR2 as described above. To remove terminal sialic acids, we incubated the cultures for $1 \mathrm{~h}$ in VCN $\left(20 \mathrm{mU} / \mathrm{ml}\right.$ at $\left.37^{\circ} \mathrm{C}\right)$. Lysis and affinity precipitation with MAG-Fc (2 $\mu \mathrm{g})$, AP-Nogo-66 (1 $\mu \mathrm{g})$, or control IgG (2 $\mu \mathrm{g})$ were performed as described above.
Neurite outgrowth assays. CHO-MAG cells were FACS-sorted (FACS Vantage SE), using anti-MAG mAb 513 ( $1 \mu \mathrm{g} / 10^{6}$ cells). Briefly, CHO-MAG cells were detached from culture plates with trypsin, rinsed in DMEM/10\% FBS, incubated in primary antibody for $15 \mathrm{~min}$ at room temperature, rinsed in DMEM $/ 10 \% \mathrm{FBS}$, and incubated in secondary antibody $\left(2 \mu \mathrm{g} / 10^{6}\right.$ cells) for $25 \mathrm{~min}$ (anti-mouse Alexa red). The top $20 \%$ of sorted cells was selected, resulting in a cell population expressing homogenous and high levels of MAG. Cell surface expression of MAG was confirmed by anti-MAG ( $\mathrm{mAb} 513$ ) immunocytochemistry under nonpermeabilizing conditions. Control $\mathrm{CHO}$ and $\mathrm{CHO}-\mathrm{MAG}$ cells were cultured in DMEM, 10\% dialyzed FBS, $2 \mathrm{~mm}$ glutamine, $40 \mathrm{mg} / \mathrm{L}$ proline, 0.73 $\mathrm{mg} / \mathrm{L}$ thymidine, $7.5 \mathrm{mg} / \mathrm{L}$ glycine (and 400 $\mu \mathrm{g} / \mathrm{ml} \mathrm{G} 418$ for CHO-MAG). For feeder layers 300,000 cells/well were seeded in PDL-coated $(50 \mu \mathrm{g} / \mathrm{ml})$ four-well plates and cultured overnight. DRGs were dissected from neonate (P1 or P2) pups and adult rats, incubated in $0.05 \%$ trypsin and $0.1 \%$ collagenase, triturated, and cultured in Sato ${ }^{+}$supplemented with $15 \mathrm{ng} / \mathrm{ml}$ NGF (for neonatal DRGs only) at a density of $2 \times 10^{5}$ cells/well. Adenoviral infection (AdNgR1, Ad-NgR2, and Ad-RFP; multiplicity of infection, $\sim 100$ ) of DRGs was performed for $3-6 \mathrm{~h}$ in PDL-coated four-well plates. After viral transfection the DRGs were detached gently from culture plates, rinsed in Neurobasal medium, transferred onto $\mathrm{CHO}$ or $\mathrm{CHO}-\mathrm{MAG}$ feeder layers, and cultured in Sato ${ }^{+}$for $18-20 \mathrm{~h}$.

Cerebellar granule neurons (CGNs) from P7 rat pups were purified in a discontinuous Percoll gradient (Hatten, 1985). CGNs at the 35/ $60 \%$ Percoll interface were collected, rinsed, and cultured in Neurobasal medium with $1 \times$ B27 supplement, $25 \mathrm{~mm}$ glucose, $1 \mathrm{~mm}$ glutamine, and Pen/Strep. For transfection of CGNs the Amaxa Biosystems (Köln, Germany) nucleofection technology was used. Briefly, $5-7 \times 10^{6}$ CGNs in $100 \mu$ of Nucleofector kit $\mathrm{V}$ solution were mixed with $3 \mu \mathrm{g}$ of pEGFP-N1 plasmid DNA or a mixture of $3 \mu \mathrm{g}$ of pMT21NgR2 and $1 \mu \mathrm{g}$ of pEGFP-N1 plasmid DNA and transferred into a cuvette for electroporation. Cells were transfected by using the $\mathrm{O}-03$ pulsing parameter, transferred into $0.5 \mathrm{ml}$ of $37^{\circ} \mathrm{C}$ prewarmed Neurobasal medium containing $10 \%$ FBS, and incubated for $30 \mathrm{~min}$ at $37^{\circ} \mathrm{C}$. Cells were rinsed once in culture medium and plated on monolayers of $\mathrm{CHO}$ or CHO-MAG cells in six-well plates for $20 \mathrm{~h}$ at a density of 1 million per well.

For neurite outgrowth on MAG spots the MAG-containing substrata were prepared from either CHO-MAG cells or adult rat spinal cord as described (Vyas et al., 2002). Briefly, CHO-MAG cells from 10 confluent $10 \mathrm{~cm}$ plates or adult rat spinal cord tissue were homogenized in ice-cold $0.32 \mathrm{~m}$ sucrose, $50 \mathrm{~mm}$ HEPES, $1 \mathrm{~mm}$ DTT, and protease inhibitor. Membranes were isolated in a sucrose gradient, followed by two osmotic shocks (Norton and Poduslo, 1973). Recombinant MAG from CHOMAG cell membranes was extracted in $60 \mathrm{~mm}$ 3-[(3-cholamidopropyl) dimethylammonio]-1-propanesulfonate (CHAPS). Endogenous MAG from adult rat spinal cord membranes was extracted in $1 \%$ octylpyranoglucoside. Protein concentrations of extracts were determined by using the BCA kit. ELISA with anti-MAG 513 confirmed the presence of MAG in both extracts (data not shown). Recombinant MAG extract $(1 \mu \mathrm{g} / \mu \mathrm{l}$ total protein) in CHAPS solution and endogenous MAG extract $(1 \mu \mathrm{g} / \mu \mathrm{l}$ 
total protein) in octylpyranoglucoside solution were incubated with either control COS or NgR2-COS membranes $(5 \mu \mathrm{g} / \mu \mathrm{l}$ total protein each) at a ratio of $1: 3$ for $1 \mathrm{~h}$ on ice. Detergents in MAG extracts caused COS membranes to dissolve completely. As a control, MAG extracts were incubated with anti-MAG (mAb 513; 0.1 $\mu \mathrm{g} / \mu \mathrm{l}$ dialyzed against Neurobasal medium) at a ratio 1:3. Each of the three mixtures $(3 \mu \mathrm{l} /$ well) then was spotted on PDL-coated (100 $\mu \mathrm{g} /$ ml) 96-well plates (in triplicates), air dried, incubated for $15 \mathrm{~min}$ in 5\% dialyzed FBS, and rinsed once in $1 \times$ PBS. To each well 35,000 Percoll-purified P7 CGNs were added, and plates were incubated at $37^{\circ} \mathrm{C} / 5 \% \mathrm{CO}_{2}$ in a humidified incubator. After $20 \mathrm{~h}$ in SATO ${ }^{+}$medium the cultures were fixed and stained with TuJ1.

Quantitative analysis of neurite length. All fluorescence pictures were taken with an IX71 Olympus (Melville, NY) inverted microscope attached at the side to a DP70 digital camera. For quantification of neurite length, pictures of dissociated DRGs or CGNs with processes equal to or longer than approximately one cell body diameter were taken. Neurite length was measured from digitized images by UTHSCSA Image Tool for Windows, version 3.0. The mean and SEM of neurite-bearing cells were calculated from at least three to six independent experiments. Data were analyzed by one-way ANOVA, followed by Dunn's post hoc analysis or Student's $t$ test with SigmaStat 3.0. All error bars that are shown indicate SEM.

\section{Results}

The Nogo receptor family members NgR1, NgR2, and NgR3 are expressed strongly in the adult brain

We identified two leucine-rich repeat (LRR) proteins in rat with a domain arrangement identical to $\mathrm{NgR} 1$, termed NgR2 and NgR3 (Fig. 1A). Toward their N-terminal end NgR1, NgR2, and NgR3 feature a characteristic and highly conserved array of eight LRRs. The LRRs are flanked N-terminally (LRRNT) and C-terminally (LRRCT) by cysteine-rich capping sequences. The LRRNT+LRR+ LRRCT domains, hereafter called the LRR cluster, are connected via a less-conserved stalk sequence ("unique" domain) to a glycosylphosphatidylinositol (GPI) anchor for membrane attachment (Fig. 1A). The same molecules have been identified independently (Barton et al., 2003; Klinger et al., 2003; Lauren et al., 2003; Pignot et al., 2003).

To begin to examine endogenous protein expression of $\mathrm{NgR}$ family members (NgRs), we raised rabbit immune sera directed against the less-conserved LRRCT and unique domain sequences of NgR1, NgR2, and NgR3. The resulting immune sera are specific as revealed by immunocytochemistry and immunoblotting of recombinant and endogenously expressed NgRs (Fig. 1B,C). In transfected COS-7 cells the myc-epitope-tagged $\mathrm{NgR} 1, \mathrm{NgR} 2$, and NgR3 are expressed abundantly and detected selectively by anti-NgR1, anti-NgR2, and anti-NgR3 antibodies, respectively.
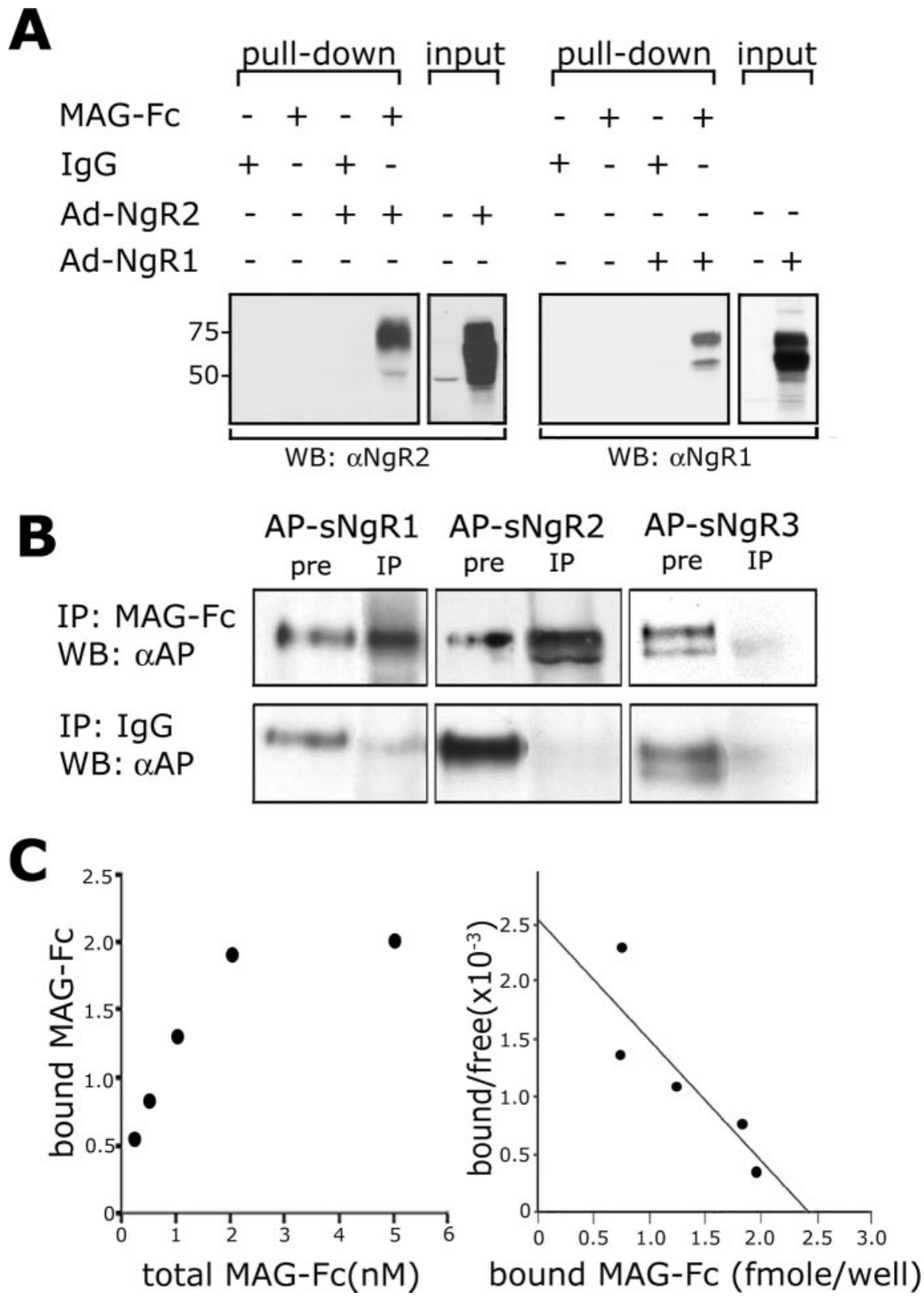

Figure 3. $\mathrm{NgR2}$ binds MAG directly and with high affinity. $A, M A G-F($ affinity precipitation of $\mathrm{NgR} 1 \mathrm{and} \mathrm{NgR} 2$ from lysates of Ad-NgR1-transduced (right) or Ad-NgR2-transduced (left) COS-7 cells. Lysates of virus-infected or control (uninfected) cells were subjected to affinity precipitation with MAG-Fc or control lgG. Immunoblotting with anti-NgR1 and anti-NgR2 revealed binding of MAG to NgR2 and NgR1 (pull-down). Of note, MAG binds selectively to the high-molecular-weight forms of NgR2 and preferentially to the higher-molecular-weight forms of NgR1. The input lanes show immunoblots of total cell lysate of control, Ad-NgR1-, and Ad-NgR2-transduced cells. B, MAG-Fc directly binds to soluble NgR1 (AP-sNgR1) and NgR2 (AP-sNgR2), but not to NgR3 (AP-sNgR3). A control lgG does not bind to any of the soluble Nogo receptors. Input (pre) and precipitates (IP) were analyzed by immunoblotting with anti-AP. C, Scatchard analysis of NgR2-transfected COS-7 cells to increasing concentrations of MAG-FC $\left(0.1-5 \mathrm{~nm}\right.$ ) produced a linear plot revealing an apparent $K_{\mathrm{D}}$ of $2 \mathrm{~nm}$ (a representative plot of 3 independent experiments is shown on the right). The graph on the left shows the MAG-Fc saturation binding curve to NgR2-expressing COS-7 cells.

Endogenously expressed receptors in adult brain extracts migrate at apparent molecular weights of $65 \mathrm{kDa}(\mathrm{NgR} 1), 65 \mathrm{kDa}(\mathrm{NgR} 2)$, and as multiple bands between 35 and $90 \mathrm{kDa}(\mathrm{NgR} 3)$. Multiple forms of recombinant $\mathrm{NgR} 3$ with a molecular weight distribution similar to the one reported here have been described previously (Pignot et al., 2003). In summary, the antisera raised against the C-terminal portion of $\mathrm{NgR} 1, \mathrm{NgR} 2$, and $\mathrm{NgR} 3$ are specific and allow selective detection of endogenously expressed NgR family members in the adult brain. 


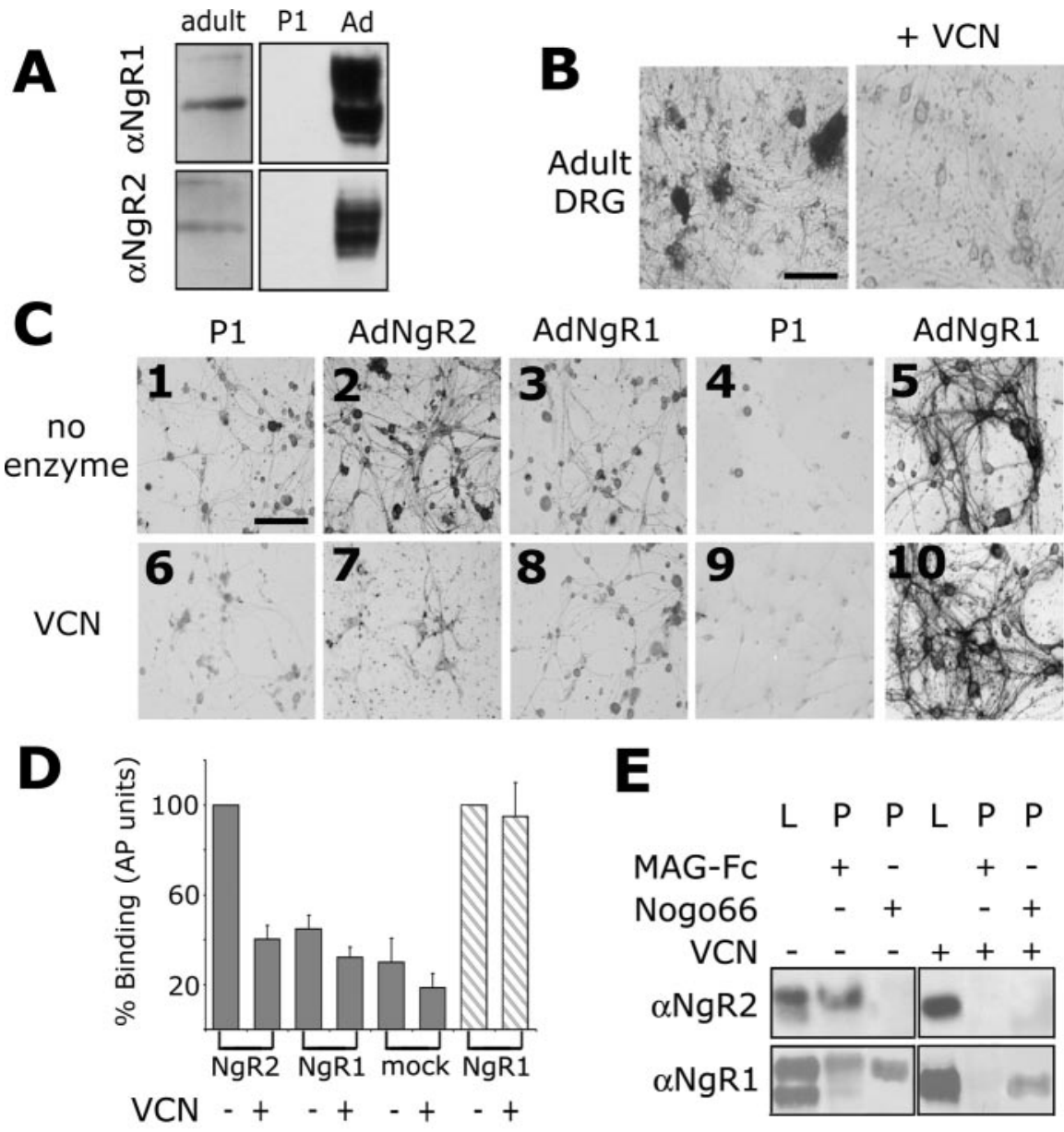

$\mathbf{F}$

dance with recent reports, AP-tagged Nogo-66 (AP-Nogo-66), chimeric MAG ectodomain (MAG-Fc), and the APtagged ectodomain of OMgp (OMgp-AP) avidly bind to recombinant NgR1 expressed in COS-7 cells (Fournier et al., 2001; Domeniconi et al., 2002; Liu et al., 2002; K. C. Wang et al., 2002a; Barton et al., 2003). In marked contrast, neither NgR2 nor NgR3 supports binding of APNogo-66 or OMgp-AP (Fig. 2A). Interestingly, NgR2, but not NgR3, supports highaffinity binding of MAG-Fc, suggesting that NgR2 is a selective binding partner for MAG. To examine whether inhibitory domains of Nogo-A other than Nogo-66 interact with $\mathrm{NgR}$ family members, we generated AP-NiG, an amino-Nogo fragment with strong inhibitory activity (Oertle et al., 2003). No binding of AP-NiG to NgR1, NgR2, or NgR3 was observed (Fig. 2A). This suggests that NgRs are not receptors for amino-Nogo. Thus the Nogo receptor family members NgR1 and NgR2 are cell surface proteins with distinct, yet partially overlapping, binding preferences for myelin-derived inhibitors of axonal growth.

Because a previous study reported that NgR2 does not support MAG binding (Barton et al., 2003), we performed several control experiments to confirm the specificity of the MAG-NgR2 association. To exclude binding of the $\mathrm{Fc}$ portion (of MAG-Fc), rather than the MAG ectodomain to $\mathrm{NgR} 2$, we examined binding of an AP-Fc fusion protein. As shown in Figure $2 B$, soluble AP-Fc does not bind to NgR2. The dimerized ectodomain of Siglec 3 (Siglec $3-\mathrm{Fc}$ ), a MAG-related protein, does not bind to NgR2 in COS-7 cells (Fig. 2B). More importantly, the monoclonal antiMAG IgG (mAb 513), previously shown specifically to block MAG-Fc binding to neurons (Collins et al., 1997), selectively blocks the NgR2-MAG interaction. A control antibody, anti-p75 IgG, does not block the NgR2-MAG association (Fig. $2 B, C$ ).

Next we asked whether NgR2 and MAG-Fc interact in solution. COS-7 cells transduced with the adenoviral vectors Ad-NgR1 or Ad-NgR2 express high levels of NgR1 and NgR2 (Fig. 3A). Lysates of viral vector-transduced cells then were subjected to affinity precipitation with MAG-Fc or control IgG. Consistent with our binding studies in COS-7 cells, MAG-Fc binds more avidly to NgR2 than

\section{MAG binds to NgR2 with high affinity}

The structural similarities among NgR1, NgR2, and NgR3, coupled with their strong expression in the adult brain (Fig. 1C), prompted us to ask whether $\mathrm{NgR} 2$ and $\mathrm{NgR} 3$ support binding of any of the previously identified NgR1 ligands (Fig. $2 \mathrm{~A}$ ). In accor- to NgR1. A control IgG forms a complex with neither NgR1 nor NgR2 (Fig. 3A). Of note, MAG binds preferentially to higher (presumably fully glycosylated) molecular weight forms of NgR2. A similar but less-pronounced binding preference was observed toward the larger forms of NgR1 (Fig. 3A). Next, to examine 
whether MAG-Fc binds NgR1 and NgR2 directly, we performed affinity precipitation experiments with MAG-Fc and soluble AP-tagged Nogo receptors (APsNgR1, AP-sNgR2, and AP-sNgR3) isolated from serum-free supernatants of transiently transfected HEK293T cells. AP-sNgR1 and AP-sNgR2, but not AP-sNgR3, form a complex with MAG-Fc (Fig. 3B). This indicates that the ectodomain of MAG interacts with NgR1 and NgR2 directly.

In a semi-quantitative experiment we compared the binding of serially diluted MAG with NgR1 and NgR2 expressed in COS-7 cells (supplemental Fig. 1, available at www.jneurosci.org as supplemental material). The experiment confirmed that MAG binds with higher affinity, approximately four to eight times stronger, to $\mathrm{NgR} 2$ than to $\mathrm{NgR} 1$. In COS-7 cells the coexpression of $\mathrm{NgR} 1$ and NgR2 does not enhance MAG binding when compared with NgR2 alone (data not shown). To measure directly the affinity of the MAG-NgR2 association, we performed a Scatchard plot analysis of MAG-Fc binding to NgR2-expressing COS-7 cells (Fig. 3C). Plotting of the saturation binding data revealed an apparent $K_{\mathrm{D}}$ of $2 \mathrm{nM}$. Previously determined affinity constants for the NgR1-MAG interaction are 8 and 20 nM (Domeniconi et al., 2002; Liu et al., 2002). Together, our studies reveal that MAG exhibits the following binding preferences for NgR family members: NgR2 > NgR1 $\gg$ NgR3.

Ectopic expression of $\mathrm{NgR} 2$ in neonate neurons is sufficient to confer sialic acid-dependent binding of MAG

Neonatal DRG neurons express very low levels of NgR1 and NgR2 and support MAG binding poorly when compared with adult DRGs (Fig. 4). Consistent with this observation, immunoblotting of cultured DRG neurons revealed stronger expression of $\mathrm{NgR} 1$ and $\mathrm{NgR} 2$ in adulthood (Fig. $4 A$ ). To examine whether ectopic expression of NgR1 or NgR2 in P1-P2 DRG neurons is sufficient to confer MAG binding, we transduced cultures with Ad-NgR1 and Ad-NgR2. Virally transfected neurons express high levels of NgR1 and NgR2 (Fig. 4A). Consistent with studies in COS-7 cells, Ad-NgR1- and Ad-NgR2-transduced DRG neurons support the binding of MAG-Fc. Moreover, MAG shows preferential binding to NgR2 (Fig. 4C,D). To assess whether neuronally expressed NgR1 and NgR2 support MAG binding in a sialic aciddependent manner, we treated virally transduced cultures with VCN. Quantification of MAG binding to DRG neurons after VCN treatment revealed a 60 and $31 \%$ decrease to Ad-NgR2- and Ad-NgR1transduced cultures, respectively (Fig. $4 C, D)$. Consistent with pervious studies (DeBellard et al., 1996), MAG binding to uninfected DRG cultures is also VCNsensitive (Fig. 4D). Binding of Nogo-66 to Ad-NgR1-transduced DRG cultures, however, is not sensitive to VCN treatment (Fig. 4C,D). To address directly whether MAG binds to NgR1 and NgR2 in a sialic acid-dependent manner, we performed af-
B

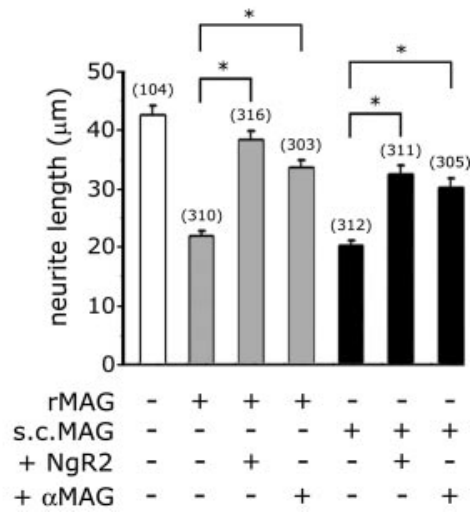
$+\mathrm{NgR} 2$

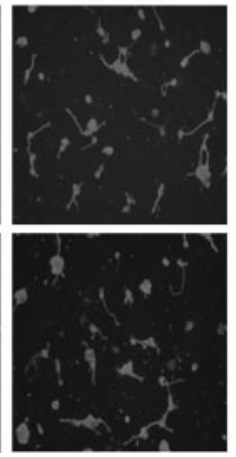

Figure 5. Exogenous NgR2 antagonizes MAG inhibition. A, Neurite outgrowth of P7 CGNs on detergent extracts of CH0-MAG cells containing recombinant MAG (rMAG) and adult rat spinal cord containing endogenous MAG (s.c.MAG). Recombinant and

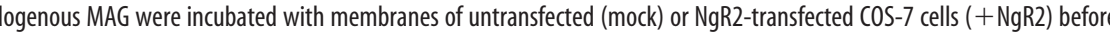
列 inhibition. A similar effect was achieved when MAG extracts were preincubated with anti-MAG (mAb 513), a function-blocking MAG antibody. The number of neurites quantified for each condition is indicated in parentheses. Results are presented as the mean \pm SEM from three independent experiments. ${ }^{*} p<0.05$, significantly different from CGNs grown on rMAG and s.c.MAG; Kruskal-Wallis one-way ANOVA ( post hoc Dunn's test). Scale bar, $40 \mu \mathrm{m}$.

finity precipitation experiments from DRG lysates using MAGFc. As shown in Figure 4E, MAG-Fc forms a complex with NgR2 and, to a lesser extent, with NgR1 in lysates of virally transduced DRGs. MAG-Fc preferentially interacts with the highermolecular-weight forms of neuronally expressed NgR1 and NgR2 (Fig. $4 E$ ). In stark contrast, when pretreated with VCN, NgR1 and NgR2 no longer complex with MAG-Fc. NgR1 maintains Nogo-66 binding in VCN-treated cultures (Fig. 4E). Moreover, we observed a $\sim 2-3 \mathrm{kDa}$ drop in the molecular weight of $\mathrm{NgR} 1$ and $\mathrm{NgR} 2$ in virally transduced DRG cultures treated with VCN (Fig. 4E). Importantly, a similar VCN-dependent shift in molecular weight was observed for endogenous NgR1 and NgR2 isolated from 2 -week-old rat brain (Fig. $4 F$ ). Together, these experiments indicate that ectopic expression of $\mathrm{NgR} 1$ and NgR2 in primary neurons is sufficient to confer MAG binding. MAG binds to NgR1 and NgR2 in a sialic aciddependent and VCN-sensitive manner. Loss of MAG binding appears to coincide with asmall but significant drop in molecular weight of $\mathrm{NgR} 1$ and $\mathrm{NgR} 2$.

\section{Exogenous NgR2 has MAG/myelin antagonistic capacity}

Given the strong affinity of NgR2 for MAG, we next examined whether exogenously added NgR2 has MAG/myelin antagonistic function. To inhibit neurite outgrowth, we plated P7 CGNs on substrata adsorbed with a detergent extract of either CHO-MAG cell membranes or adult rat spinal cord membranes that contain MAG (Vyas et al., 2002). On recombinant MAG (rMAG from

Figure 6. Ectopic $\mathrm{NgR2}$ in neonatal DRGs confers MAG inhibition. A, Neonatal DRGs transduced with Ad-NgR2 abundantly express $\mathrm{NgR2}$. Ectopic $\mathrm{NgR} 2$ is localized to neurites and growth cones, as revealed by anti-NgR2 and TuJ1 double immunofluorescence. B, DRGs transduced with Ad-NgR1 or Ad-NgR2 were seeded on confluent monolayers of CHO (control) or CHO-MAG cells. Neurons expressing ectopic $\mathrm{NgR} 1$ or $\mathrm{NgR2}$ were identified by double immunofluorescence labeling with anti-NgR1 or anti-NgR2 and TuJ1. C, Quantification of neurite length. Neurites of untransduced or Ad-RFP-transduced DRGs on CH0-MAG are 15 and $20 \%$ longer than on CHO feeder layers, respectively. DRGs infected with Ad-NgR1 or Ad-NgR2 before plating on CH0-MAG show a 22 and $32 \%$ decrease in neurite length, respectively. The number of neurites measured for each condition is indicated in parentheses. Results are presented as the mean \pm SEM from three independent experiments. ${ }^{*} p<0.05$, significantly different from Ad-RFPtransduced DRGs; Kruskal-Wallis one-way ANOVA ( post hoc Dunn's test). On CHO control cells Ad-NgR2-transduced DRGs show a small but statistically nonsignificant decrease in neurite length. Scale bar: (in B), $50 \mu \mathrm{m}$. 
A
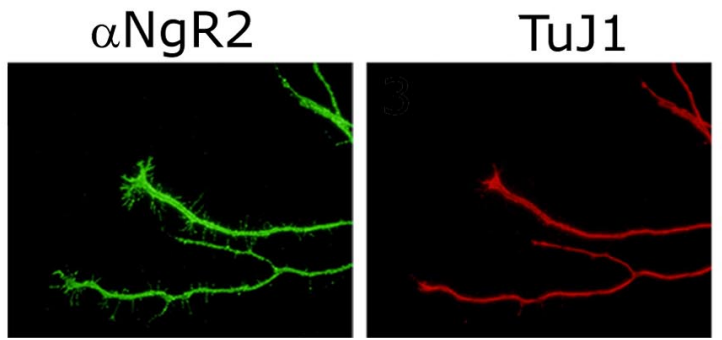

B

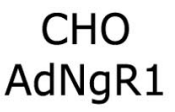

CHO-MAG AdNgR1
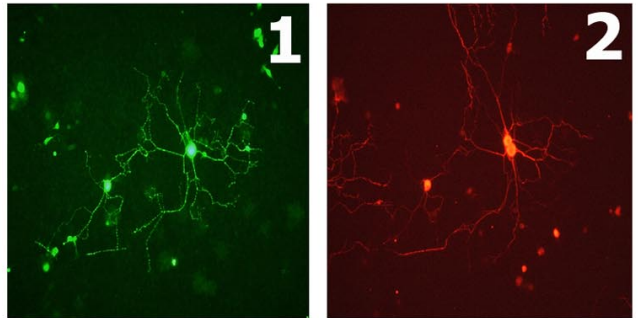

TuJ1
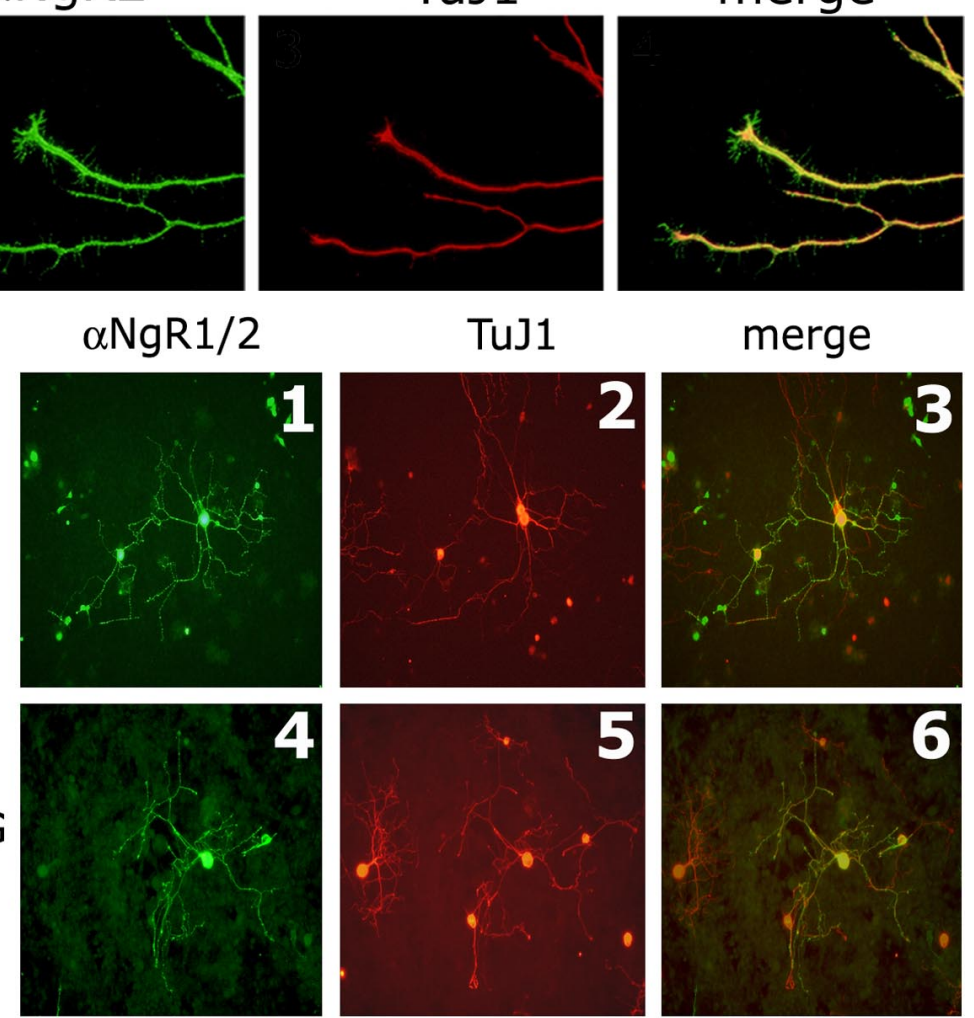

\section{$\mathrm{CHO}$ AdNgR2}
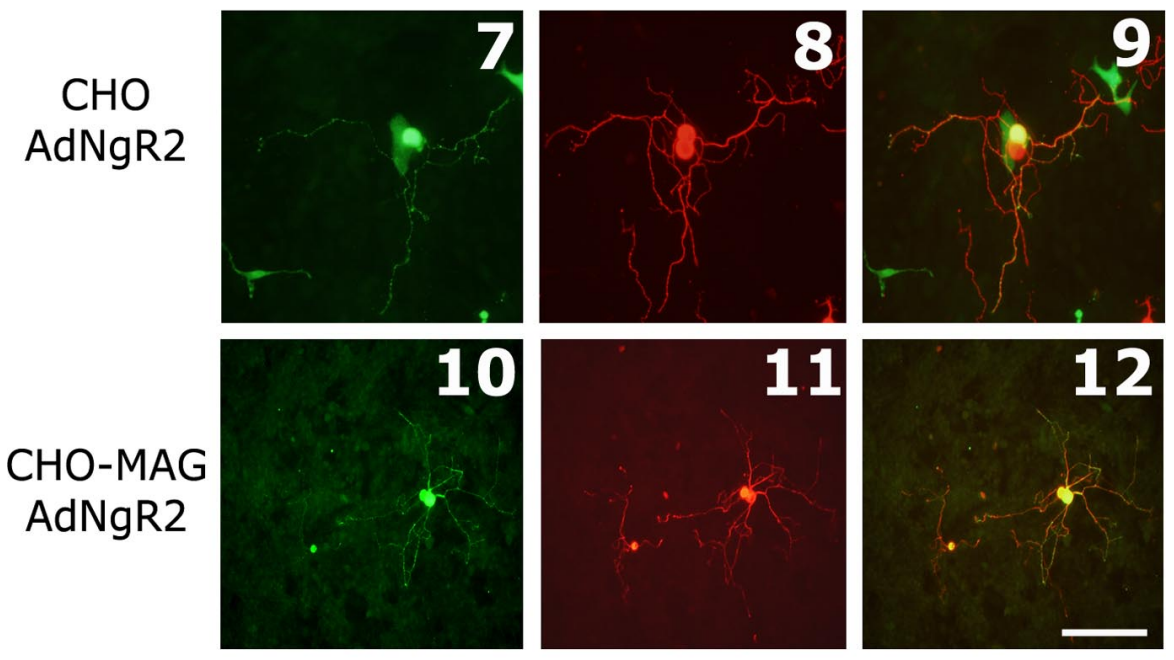

C

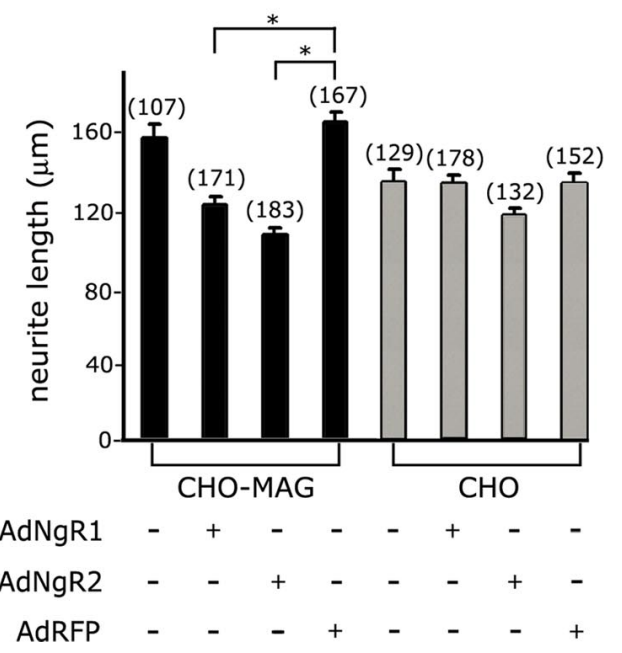

CHO-MAG cells) and endogenous MAG (s.c.MAG from spinal cord) substrate, neurite length decreases to $51 \%$ (rMAG) and $47 \%$ (s.c.MAG) of CGNs grown on control substrate (Fig. 5). To show directly that inhibition is attributable to the presence of MAG, we preincubated inhibitory extracts with anti-MAG $(\mathrm{mAb}$ 513), a function-blocking antibody. Anti-MAG greatly attenuated the inhibition of CGNs on both substrates. Neurite length increases to $81 \%$ (rMAG) and $70 \%$ (s.c.MAG) of controls (Fig. $5 B$ ). More importantly, preincubation of MAG extracts with NgR2-COS-7 membranes $(+\mathrm{NgR} 2)$ greatly attenuated inhibition of CGNs compared with MAG extracts incubated with control COS-7 membranes (mock). In the presence of exogenous $\mathrm{NgR} 2$ the neurite length increased to $89 \%$ (rMAG) and $74 \%$ (s.c. MAG) of controls (Fig. 5A,B). To rule out the possibility that exogenous NgR2 attenuates MAG inhibition indirectly via binding to $\mathrm{NgR} 1$, we asked whether $\mathrm{NgR} 1$ interacts with NgR2. As shown in supplemental Figure 2 (available at www. jneurosci.org as supplemental material), affinity precipitation with $\mathrm{NgR} 1-\mathrm{Fc}$ from lysates of Ad-NgR2-transduced COS cells did not reveal an NgR1-NgR2 association. As a positive control we show that NgR1-Fc binds strongly to APNogo-66, but not to AP-NiG. Thus soluble NgR1 and NgR2 do not appear to interact with each other. Taken together, our experiments suggest that binding of soluble NgR2 masks the growth inhibitory domain or domains of MAG and that exogenous NgR2 has MAG/myelin antagonistic capacity in vitro.

Ectopic expression of NgR2 in neonate DRG neurons is sufficient to confer MAG inhibition

MAG is a bifunctional guidance molecule; it promotes growth of young neurons and inhibits growth at more mature stages. Consistent with previous reports, we observed that MAG promotes neurite growth of neonatal DRG neurons (Johnson et al., 1989). When cultured on monolayers of CHO-MAG or $\mathrm{CHO}$ cells, neurites of P1-P2 DRGs grow 15-20\% longer on CHO-MAG than on $\mathrm{CHO}$ substrate (Fig. 6). To ask whether ectopic NgR1 or NgR2 is sufficient to confer MAG inhibition on NGF-responsive DRG neurons, we transduced dissociated DRGs for $3 \mathrm{~h}$ with Ad$\mathrm{NgR} 1$ or Ad-NgR2 before plating them on CHO-MAG or $\mathrm{CHO}$ feeder layers. After $20 \mathrm{~h}$ the cultures were fixed and stained by double immunofluorescence for neuron- 
specific class III $\beta$-tubulin (TuJ1) and $\mathrm{NgR} 1$ or NgR2. Ectopic NgR2 and NgR1 (data not shown) are localized to cell bodies, neurites, and growth cones of transduced neurons (Fig. 6A). Quantification of neurite lengths on $\mathrm{CHO}-\mathrm{MAG}$ cells revealed a decline in fiber length of $22 \%$ for $\mathrm{NgR}_{1}{ }^{+}$and $32 \%$ for $\mathrm{NgR}_{2}{ }^{+}$neurons when compared with Ad-RFP-transduced neurons. On $\mathrm{CHO}$ feeder cells the $\mathrm{NgR} 2^{+}$ DRGs show a small decrease in fiber length that is not statistically significant from AdRFP- or Ad-NgR1-transduced DRGs (Fig. $6 B, C)$. Together, these experiments show that, on MAG substrate, ectopic NgR1 and $\mathrm{NgR} 2$ lead to a significant decrease in fiber length. Thus, similar to NgR1, NgR2 functions as an inhibitory receptor for MAG.

Ectopic expression of $\mathrm{NgR} 2$ in postnatal CGNs augments the MAG

inhibitory response

In a parallel experiment to examine whether NgR2 participates in MAG inhibitory responses, we used P7 CGNs. P7 CGNs strongly express $\mathrm{NgR} 1$ and p75, but not NgR2 (Fig. 7B). On CHO-MAG feeder layers the neurite growth of P7 CGNs is reduced significantly compared with CGNs grown on $\mathrm{CHO}$ feeder layers. Because NgR2 binds MAG more strongly than NgR1, we ectopically expressed NgR2 in P7 CGN to examine whether NgR2 functions as a productive receptor that increases MAG inhibition or behaves as a dominant-negative receptor that binds MAG unproductively. In the latter case, ectopic NgR2 may sequester MAG away from NgR1 and thus lead to an increase in neurite length. Purified P7 CGNs were transfected by nucleofection (Maasho et al., 2004) and cultured on control $\mathrm{CHO}$ or CHO-MAG feeder layers (Fig. 7A). Neuronal transfection efficiencies of $>40 \%$ were achieved, as revealed by double immunofluorescence with anti-GFP and the neuronspecific antibody TuJ1. Transfected $\mathrm{GFP}^{+}$ neurons cultured on $\mathrm{CHO}$ cells grow long neurites within $24 \mathrm{~h}$ (Fig. 7A,C). When plated on $\mathrm{CHO}-\mathrm{MAG}$ monolayers, neurite outgrowth of $\mathrm{GFP}^{+}$CGNs is strongly inhibited. Quantification of neurite length of $\mathrm{GFP}^{+} \mathrm{CGN}$ on $\mathrm{CHO}-\mathrm{MAG}$ cells revealed a significant $(53 \%)$ decrease in length compared with controls on $\mathrm{CHO}$ cells (Fig. 7D). When cotransfected with $N g R 2$ and GFP plasmid DNA (ratio, 3:1), $\mathrm{GFP}^{+}$neurons coexpress NgR2, as shown by anti-NgR2 immunocytochemistry and immunoblotting of transfected CGNs lysates (Fig. 7C), and hereafter are referred to as $\mathrm{NgR} 2{ }^{+} \mathrm{CGNs}$. On $\mathrm{CHO}$ cells the neurite length of $\mathrm{NgR} 2^{+}$ $(34 \pm 3 \mu \mathrm{m})$ and $\mathrm{GFP}^{+} \mathrm{CGNs}(36 \pm 3 \mu \mathrm{m})$ is very similar. On CHO-MAG cells, how-
A
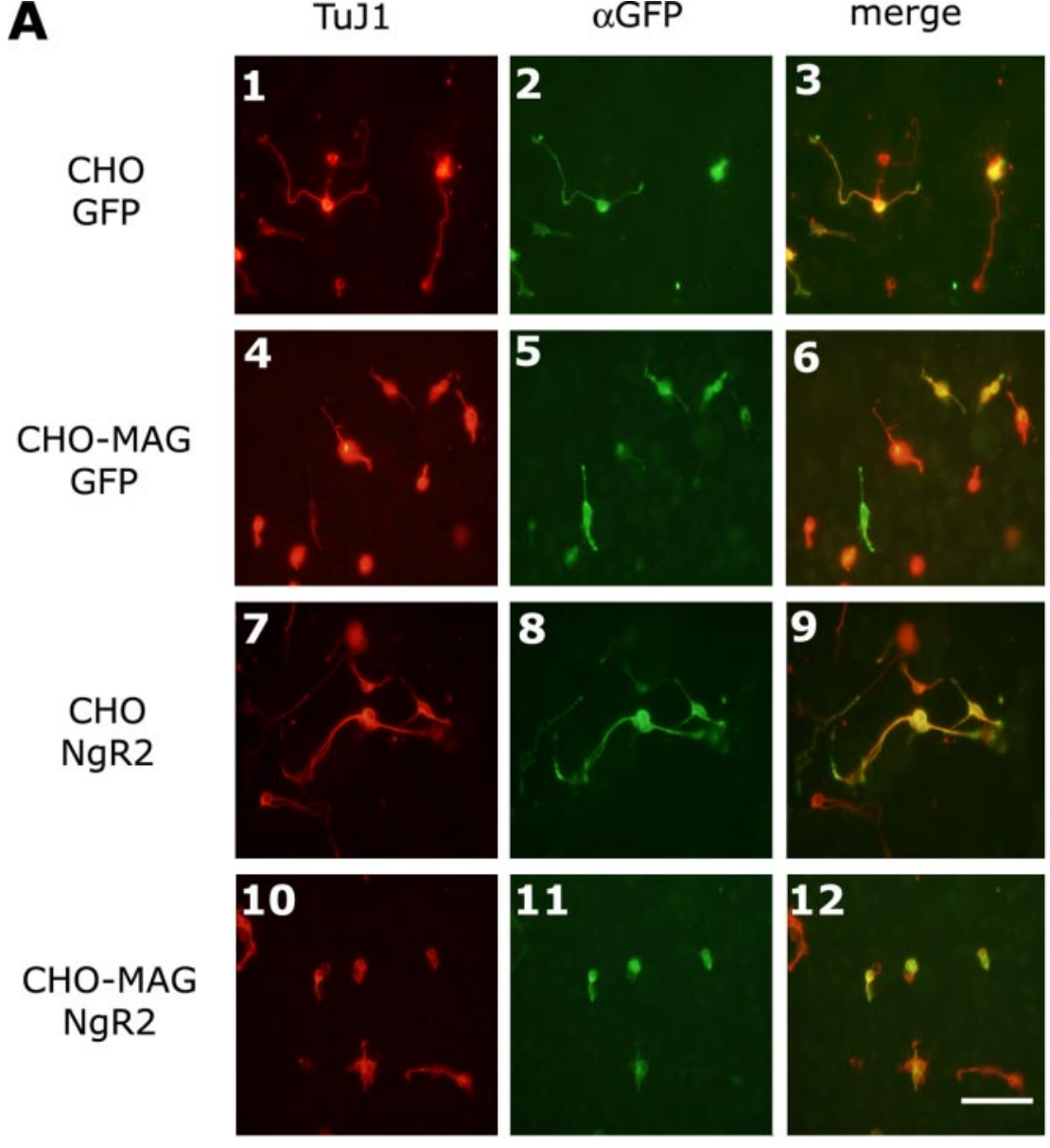

B
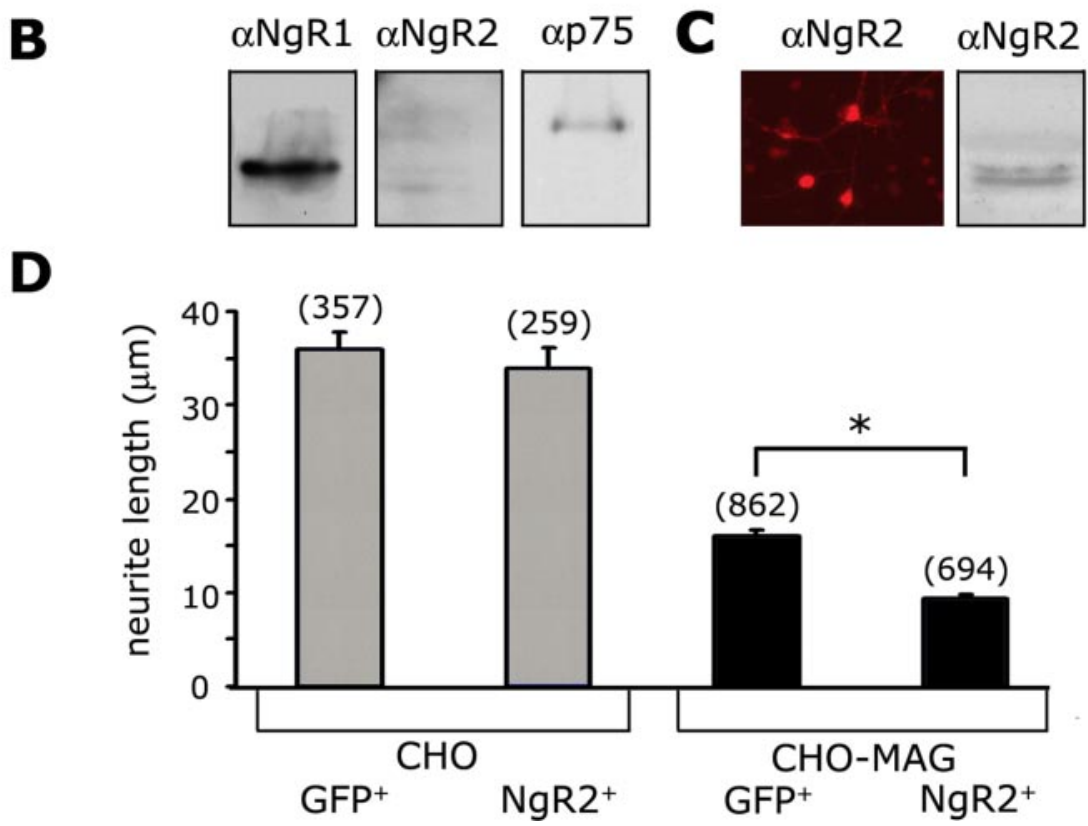

Figure 7. Ectopic expression of $\mathrm{NgR2}$ in P7 CGNs augments MAG inhibition. A, P7 rat CGNs were purified in a discontinuous Percoll gradient and transfected by nucleofection with expression plasmids for EGFP (A1-A6) and a plasmid mixture for EGFP and $\mathrm{NgR2}$ (A7-A12). After transfection, the neurons were seeded on confluent monolayers of CHO (control) or CHO-MAG cells. Transfected neurons were identified by double immunofluorescence labeling with anti-GFP (green) and TuJ1 (red). B, Immunoblotting of untransfected P7 CGN lysates revealed expression of NgR1 and p75, but not NgR2. C, After nucleofection, the CGNs express NgR2, as shown by anti-NgR2 ICC (left) and Western blot analysis (right). D, Quantification of neurite length. The number of neurites measured for each condition is indicated in parentheses. Results are presented as the mean \pm SEM from four independent experiments. ${ }^{*} p<0.008$, significantly different from GFP ${ }^{+}$CGNs on CH0-MAG cells. Fiber length of GFP ${ }^{+}$and NgR2 $^{+} \mathrm{CGNs}_{\text {on }}$ $\mathrm{CHO}$ is not significantly different; Kruskal-Wallis one-way ANOVA ( post hoc Dunn's test). Scale bar, $30 \mu \mathrm{m}$. 
A
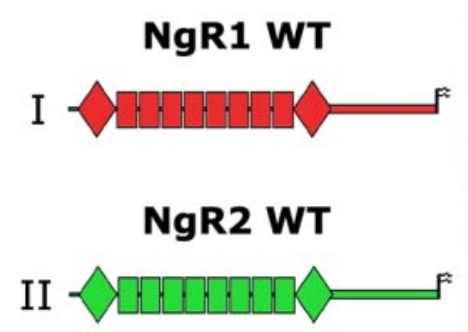

NgR1 $\Delta$ unique

NgR2 $\Delta$ unique
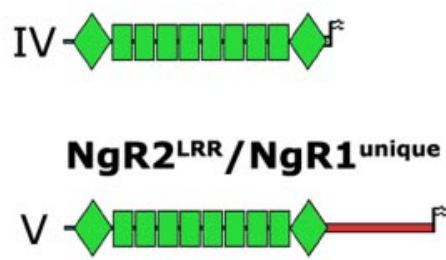

NgR1 $1^{\text {LRR }} /$ NgR2 $^{\text {unique }}$

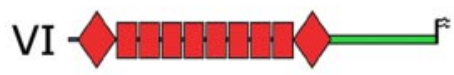

NgR3 ${ }^{\text {LRR }} / \mathrm{NgR2}^{\text {unique }}$

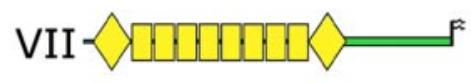

B

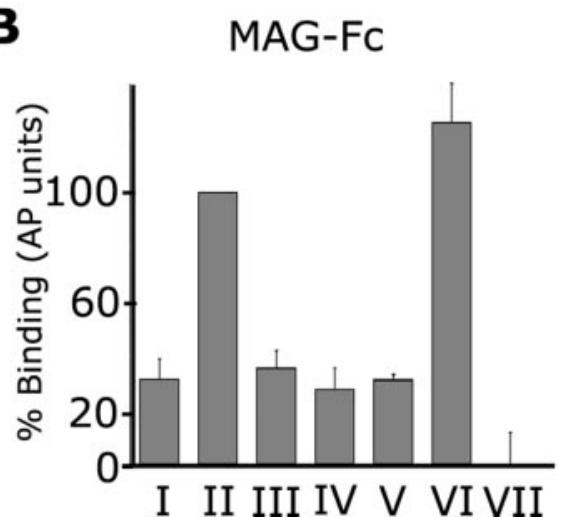

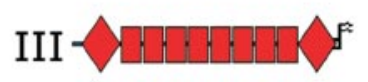
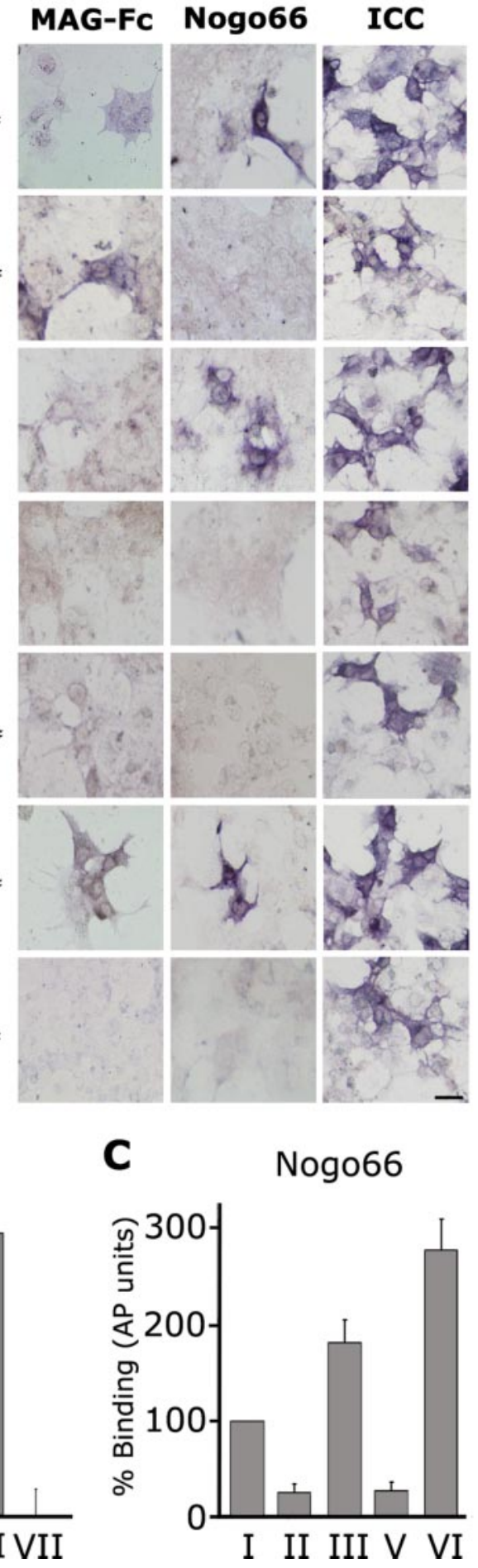

Figure 8. Structural basis of the $\mathrm{NgR2}-\mathrm{MAG}$ association. A, A chimeric receptor strategy was pursued to identify the $\mathrm{NgR2}$ domains necessary for MAG binding. Wild-type and mutant receptors were expressed transiently in COS-7 cells, and surface expression and distribution were confirmed by anti-NgR1 or anti-NgR2 ICC under nonpermeabilizing conditions. Binding of MAG-Fc was detected with an anti-human Fc AP-conjugated antibody and compared with AP-Nogo-66. Wild-type NgR1 and $\mathrm{NgR1}-\Delta$ unique support the binding of Nogo-66 and MAG. In stark contrast, wild-type NgR2, but not NgR2- $\Delta$ unique, supports high-affinity MAG binding. Thus, the NgR2-unique domain is necessary for high-affinity MAG binding. Chimera VII indicates that the $\mathrm{NgR2}$-unique domain is not sufficient for MAG binding. Of note, chimera $\mathrm{VI}$, composed of the NgR1-LRR cluster fused to the $\mathrm{NgR2}$-unique domain, supports high-affinity binding of Nogo-66 and MAG-Fc. B, Quantification of MAG-Fc (17 nm) binding to wild-type and mutant receptors in relative AP units normalized to wild-type $\mathrm{NgR2}$ (100\%). Chimera VI supports MAG binding with greater affinity than wild-type NgR2. C, Quantification of AP-Nogo-66 (10 nM) binding to wild-type and mutant receptors in relative AP units normalized to wild-type NgR1 (100\%). Constructs III and VI support AP-Nogo-66 binding with greater affinity than wild-type $\mathrm{NgR} 1$. Results are presented as the mean \pm SEM from three to five independent binding experiments, normalized to receptor cell surface expression. Scale bar, $10 \mu \mathrm{m}$. ever, $\mathrm{NgR} 2{ }^{+}$CGNs show a significant decrease $(41 \%)$ in neurite length when compared with $\mathrm{GFP}^{+}$CGNs (Fig. 7D). In summary, these experiments reveal that ectopic expression of NgR2 in CGN, a cell type that normally does not express NgR2, is sufficient to increase the MAG inhibitory response greatly. Thus we conclude that ectopic NgR2 in CGNs does not behave as a dominant-negative MAG receptor but, rather, functions as a productive receptor that mediates MAG inhibition.

Structural basis of the

NgR2-MAG association

Previous studies have shown that the NgR1-LRR cluster (NgR1Ecto ${ }^{1-310}$ ) is necessary and sufficient for the binding of Nogo-66, MAG, and OMgp (Fournier et al., 2002; K. C. Wang et al., 2002a; X. Wang et al., 2002; Barton et al., 2003). Given the high degree of conservation between NgR1 and NgR2 over the extent of the LRR cluster, we first asked whether the corresponding sequences of NgR2, including the LRRNTLRR-LRRCT domains (NgR2Ecto ${ }^{1-313}$ ), are sufficient to support high-affinity MAG binding. Consistent with pervious reports, deletion of the NgR1-unique domain $\left(\mathrm{NgR} 1^{\Delta \text { unique }}\right)$ does not alter the binding properties of NgR1 toward Nogo-66, OMgp (data not shown), or MAG-Fc. Significantly, an analogous construct of NgR2 lacking the unique domain $\left(\mathrm{NgR} 2^{\Delta \text { unique }}\right)$ supports MAG-Fc binding very poorly compared with full-length NgR2 (Fig. 8). This indicates that the NgR2Ecto ${ }^{1-313}$ is not sufficient for high-affinity MAG binding and that sequences in the NgR2-unique domain are important for MAG binding.

To examine whether the NgR2-unique domain is sufficient to support MAG binding, we fused the NgR3-LRR cluster to the NgR2-unique domain, resulting in chimera NgR3 ${ }^{\text {LRR }} / \mathrm{NgR} 2^{\text {unique }}$. Similar to wild-type NgR3 (Fig. 2A), NgR3 ${ }^{\text {LRR } / N g R 2 ~}{ }^{\text {unique }}$ does not support MAG-Fc or Nogo-66 binding (Fig. $8 A, B$ ). Together, this suggests that the $\mathrm{NgR} 2$-unique domain is necessary but not sufficient for high-affinity MAG binding. Next we asked whether the NgR1-unique domain, when fused to the NgR2-LRR cluster, restores high-affinity MAG binding and, conversely, whether the NgR2-unique domain enhances binding to the NgR1-LRR cluster. We generated two chimeric receptors, $\mathrm{NgR} 2^{\mathrm{LRR}} / \mathrm{NgR} 1^{\text {unique }}$ and $\mathrm{NgR} 1^{\mathrm{LRR}} /$ $\mathrm{NgR} 2{ }^{\text {unique }}$, in which the unique domains of NgR1 and NgR2 were swapped (Fig. 8A). Interestingly, swapping of the NgR1- and NgR2-unique domains reverses the MAG binding preferences; similar to wild-type NgR2, NgR1 ${ }^{\text {LRR }} / \mathrm{NgR} 2^{\text {unique }}$ binds MAG 
with high affinity, and, vice versa, $\mathrm{NgR} 2{ }^{\mathrm{LRR}} / \mathrm{NgR} 1$ unique binds $\mathrm{MAG}$ with lower affinity similar to wild-type NgR1 (Fig. $8 B$ ). Of note, chimera $\mathrm{NgR} 1^{\mathrm{LRR}} / \mathrm{NgR} 2^{\text {unique }}$ also binds strongly to Nogo-66 (Fig. $8 B$ ) and OMgp (data not shown). Thus chimera $\mathrm{NgR} 1^{\mathrm{LRR}}$ / $\mathrm{NgR} 2$ unique embodies the high-affinity binding capacity of NgR2 toward MAG and that of NgR1 toward Nogo-66 and OMgp. The complementary construct, chimera $\mathrm{NgR} 2^{\mathrm{LRR}} / \mathrm{NgR} 1^{\text {unique }}$, binds MAG weakly and does not support binding of Nogo-66 (Fig. 8 B) or OMgp (data not shown). Immunocytochemistry of transfected COS-7 under nonpermeabilizing conditions was used to confirm surface expression of all receptor constructs (Fig. $8 \mathrm{~A}$ ).

The relative binding affinity (in AP units) of MAG-Fc for each receptor construct was assessed quantitatively and normalized to cell surface receptor expression. The average binding affinities of MAG-Fc and AP-Nogo-66 to receptor chimera, normalized to the wild-type NgR2-MAG (=100\%) and wild-type NgR1Nogo-66 $(=100 \%)$ interaction, are shown in Figure $8, B$ and $C$. Of note, chimera NgR1 ${ }^{\mathrm{LRR}} / \mathrm{NgR} 2{ }^{\text {unique }}$ supports AP-Nogo-66 binding 2.7-fold stronger than wild-type NgR1. In addition, $\mathrm{NgR} 1^{\mathrm{LRR}} / \mathrm{NgR} 2^{\text {unique }}$ supports MAG binding with fivefold and 1.2-fold greater affinity than wild-type $\mathrm{NgR} 1$ and $\mathrm{NgR} 2$, respectively. In summary, our structural analysis of the NgR2-MAG association suggests that the NgR2-LRR cluster and the NgR2unique domain work cooperatively and are both necessary for high-affinity MAG binding. Whereas the NgR2-LRR cluster is necessary and sufficient to support MAG binding weakly, the $\mathrm{NgR} 2$-unique domain is necessary but not sufficient for highaffinity MAG binding. This is in sharp contrast to the NgR1unique domain, which is not necessary for maximal binding of MAG or Nogo-66 to NgR1. Thus the structural basis of MAG binding appears to be distinct and only partially conserved between NgR1 and NgR2. Although the NgR1 ligand-binding domain (LBD) is composed of the LRR cluster only, the NgR2 LBD is more extended, including the LRR cluster as well as sequences in the juxtaposed unique (stalk) domain.

\section{$\mathrm{NgR} 2$ is an axon-associated glycoprotein abundantly expressed in the adult brain}

Based on our functional studies in primary neurons, the selectivity, and sialic acid dependence of the MAG-NgR2 association, we hypothesized that $\mathrm{NgR} 2$ is a novel MAG receptor. If $\mathrm{NgR} 2$ is indeed a MAG receptor, protein expression is expected to be associated with projection neurons and to include axons of myelinated fiber tracts. To begin to address the tissue distribution of $\mathrm{NgR} 2$ and its relation and relative abundance to $\mathrm{NgR} 1$, we used a combination of in situ hybridization, immunohistochemistry, and tissue immunoblotting. In situ hybridization with RNA probes directed against the coding region of the less-conserved unique portions of $N g R 1$ and $N g R 2$ revealed that both transcripts are expressed broadly in the mature CNS and localized primarily to cell bodies of projection neurons. In the retina, for example, $N g R 2$ is expressed in the ganglion cell layer (GCL) and the inner segment of the inner granule cell layer (IGL), but not in the outer granule cell layer (OGL). A very similar staining pattern, but with lower intensity, was found for $N g R 1$ (Fig. 9A). To examine whether $\mathrm{NgR} 1$ and $\mathrm{NgR} 2$ are localized to axons, we performed immunohistochemistry on adult retina. In line with our in situ hybridization data and consistent with a role in axon-glia interaction, anti-NgR1 and anti-NgR2 IgG decorate retinal cell soma in the GCL and axons of the optic fiber layer (OFL). In addition, cell bodies in the IGL are labeled with anti-NgR2 and to a lesser extent with anti-NgR1 (Fig. 9A). In cross sections of adult spinal cord $\mathrm{NgR} 2$ expression is restricted to gray matter and is absent from white matter. Particularly robust labeling is confined to presumptive motor neurons in the ventral horn. Many large- and small-caliber sensory neurons in DRGs express $\mathrm{NgR} 2$; the expression appears broad but heterogeneous, with some neurons being labeled more intensely (Fig. 9B). To study the relative abundance of NgR1 and NgR2 in different brain regions, we dissected specific areas and subjected them to immunoblotting, using our anti-NgR1- and anti-NgR2-specific immune sera (Fig. 9C). Consistent with histochemical studies (Fig. 9A,B) (Pignot et al., 2003), both receptors are expressed broadly in the CNS, including retina, olfactory bulb, septum, neocortex, entorhinal cortex, hippocampus, striatum, and thalamus (Fig. 9C). Although expression of NgR1 and NgR2 appears to be very broad, we also noticed clear differences in the relative abundance of $\mathrm{NgR} 1$ and $\mathrm{NgR} 2$ within specific brain regions. In the retina, for example, $\mathrm{NgR} 2$ is much more prominent than $\mathrm{NgR} 1$; conversely, in the thalamus $\mathrm{NgR} 1$ is more prominent than NgR2. Robust expression of $\mathrm{NgR} 1$ and $\mathrm{NgR} 2$ is found in the neocortex, entorhinal cortex, hippocampus, and striatum (Fig. 9C). Much weaker expression of $\mathrm{NgR} 1$ and $\mathrm{NgR} 2$ is observed in the olfactory bulb and the septum. Taken together, the tissue distribution patterns of $\mathrm{NgR} 1$ and NgR2 are overlapping, yet distinct, including numerous populations of projection neurons. Moreover, NgR2, similar to NgR1 (X. Wang et al., 2002), is found on myelinated axons. Given that MAG is localized to myelin sheets immediately adjacent to the axon (Trapp et al., 1989), NgR1 and NgR2 are well positioned to function as neuronal MAG receptors in vivo.

\section{Neural NgR2 is localized to lipid rafts}

Recent studies have shown that a number of neuronal receptors that regulate axon growth and guidance are associated with cholesterol- and sphingolipid-enriched membrane microdomains called lipid rafts (Tsui-Pierchala et al., 2002; Guirland et al., 2004). Specifically, several MAG receptor components, including NgR1, p75, and GT1b, are localized to lipid rafts (Vinson et al., 2003). Because MAG in myelinating glia also is associated with lipid rafts, a model has been proposed in which MAG function involves lipid raft-to-lipid raft interaction on opposing cell membranes. To begin to address whether NgR2 may participate in such interactions, we isolated Triton X-100insoluble caveolin-positive membrane fractions from $\mathrm{P} 14$ rat brain. Immunoblotting with anti-NgR1 and anti-NgR2 revealed that both receptors are found nearly exclusively within lipid rafts (Fig. 9D). Thus NgR2 may be part of a bidirectional signaling system that regulates MAG inhibition of neurite outgrowth and maintenance of myelin integrity.

\section{Discussion}

Here we report on the identification of $\mathrm{NgR} 2$ as a neuronal MAG receptor that functions in neurite growth inhibition. NgR2 supports high-affinity and sialic acid-dependent binding of MAG. Consistent with a role as MAG receptor, NgR2 is expressed in postnatal and adult neurons and localized to axons of myelinated fiber tracts. Ectopic expression of NgR2 in neonatal DRG neurons is sufficient to inhibit growth on MAG substrate. In more mature neurons the ectopic expression of $\mathrm{NgR} 2$ augments the MAG inhibitory response, indicating that NgR2 is a functional MAG receptor. Soluble NgR2 has MAG antagonistic function and promotes neurite growth on myelin substrate in vitro. Finally, molecular studies of the NgR2-MAG association revealed that the LRR cluster and unique domain of NgR2 are necessary for high-affinity MAG binding. Taken together, our results sug- 
A

mRNA

protein
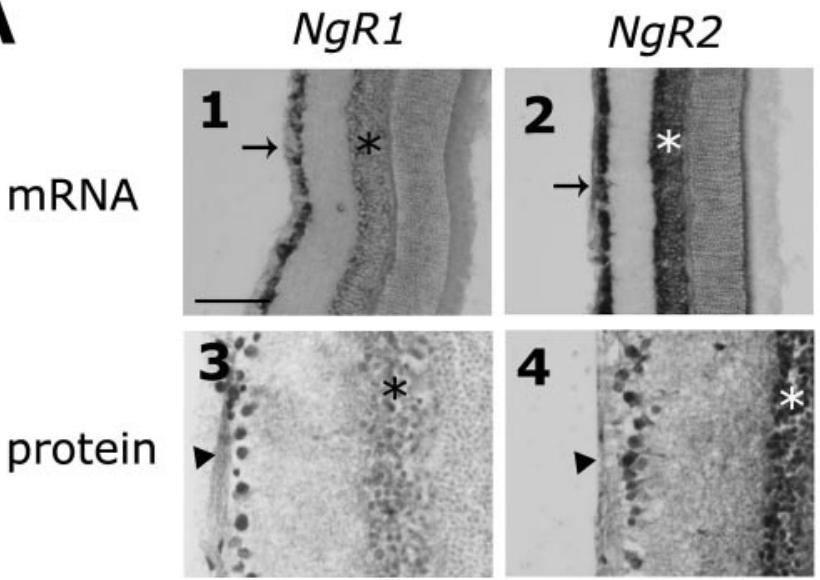

C

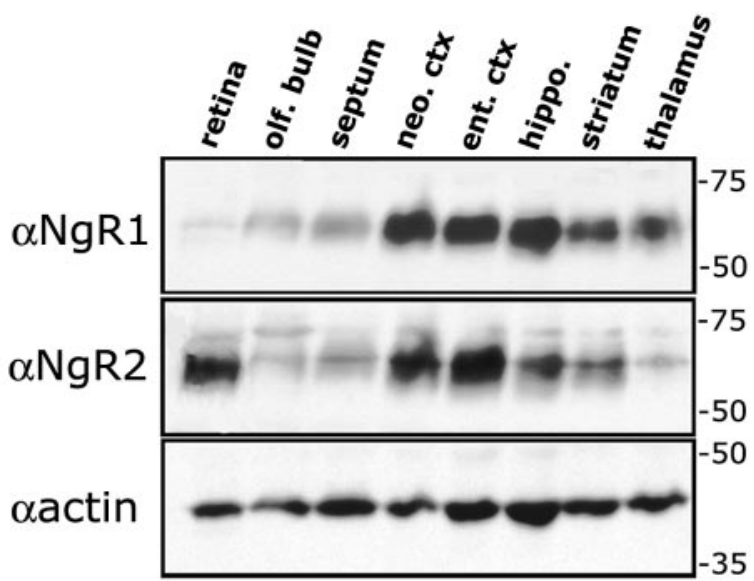

$-35$
B

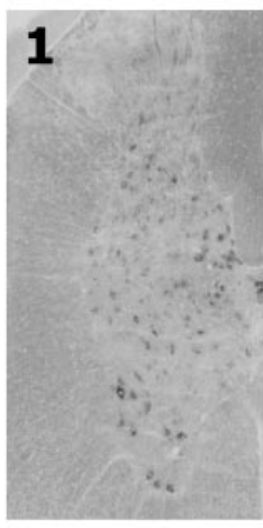

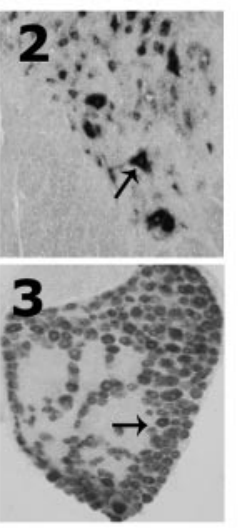

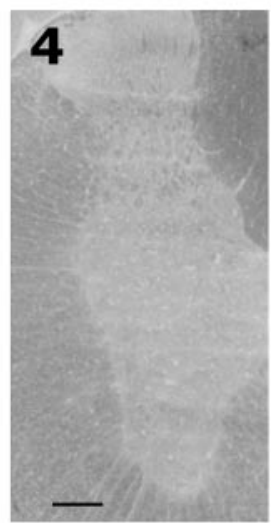

D

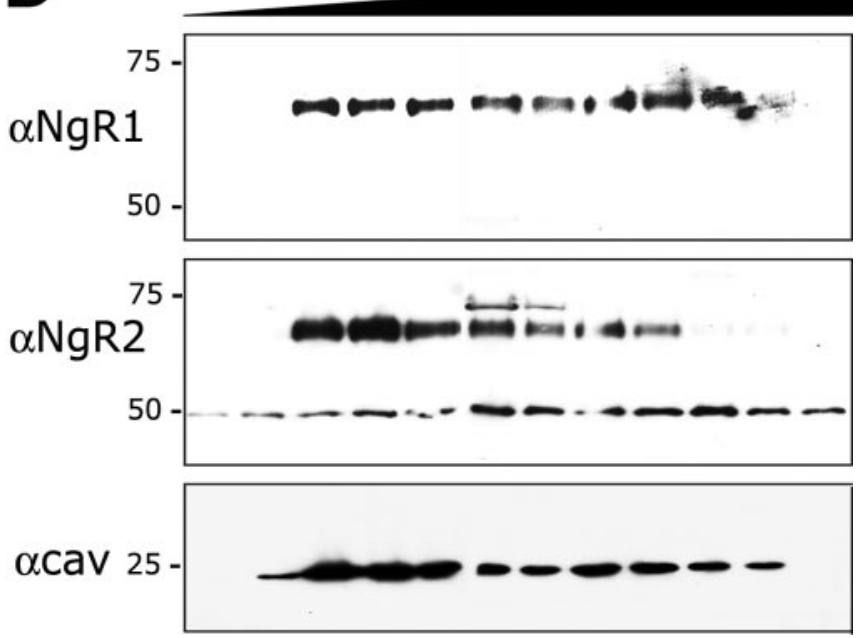

Figure 9. $\mathrm{NgR2}$ is an axon-associated receptor broadly expressed in the postnatal and adult CNS. A, Comparison of NgR1 and NgR2 expression in adult retina of the rat. In situ hybridization shows expression of $\mathrm{NgR1}(A 1)$ in presumptive retinal ganglion cells (RGCs; arrow) and the inner part of the IGL; see asterisk. A very similar but more robust expression in the retina was observed for $\mathrm{NgR2}$ (A2). Consistent with the mRNA distribution, anti-NgR1 and anti-NgR2 label the cell bodies of RGCs and axons in the optic fiber layer (arrowhead). Anti-NgR1 labels the IGL weakly, and anti-NgR2 labels the IGL strongly (asterisk). $B$, Cross section of adult spinal cord at mid-thoracic level; dorsal is to the top ( $B 1, B 2, B 4) . N g R 2$ is expressed broadly in spinal gray matter but is absent from white matter $(B 1, B 2)$. Strong labeling is associated with presumptive motor neurons in the ventral horn ( $B 2$, arrow). Many small- and large-caliber sensory neurons in adult DRGs express NgR2 (B3). Strongly labeled DRG cells (arrow) are interspersed with weakly labeled cells (B3). No signal was detected with a DIG-labeled sense RNA probe (B4). C, Anti-NgR1 and anti-NgR2 immunoblot of different brain regions revealed broad expression of $\mathrm{NgR} 1$ and $\mathrm{NgR2}$ in the mature CNS. The same blot was probed serially with anti-NgR2, anti-NgR1, and anti-actin (as a loading control); see Results for details. D, In brain, the NgR1 and NgR2 are localized to lipid rafts. Triton X-100-insoluble lipid rafts were isolated from P14 brain extracts by flotation in a sucrose gradient and were subjected to immunoblotting with anti-NgR1, anti-NgR2, and anti-caveolin. Scale bars: $A 1, A 2,200 \mu \mathrm{m} ; A 3, A 4, B 2, B 3,100 \mu \mathrm{m} ; B 1, B 4,250 \mu \mathrm{m}$.

gest that $\mathrm{NgR} 2$, together with $\mathrm{NgR} 1$, coordinates MAG/myelin inhibitory neuronal responses.

\section{NgR2 supports MAG binding in a sialic acid-dependent manner}

MAG is a sialic acid-binding lectin, and multiple lines of evidence show that MAG inhibits growth in a sialic acid-dependent manner (DeBellard et al., 1996; Shen et al., 1998; Vinson et al., 2001; Vyas et al., 2002). Sialic acid binding alone, however, is not sufficient to bring about MAG inhibition (Tang et al., 1997). This suggests that in a functional recognition complex MAG is engaged in multiple interactions, at least one of which is sialic aciddependent. Complex gangliosides have been identified as sialic acid-dependent MAG ligands that function in growth inhibition (Yang et al., 1996; Collins et al., 1997; Vinson et al., 2001; Vyas et al., 2002). In addition, binding of MAG-Fc to primary neurons and neuroblastoma cells is trypsin- and VCN-sensitive (DeBellard et al., 1996; DeBellard and Filbin, 1999; Strenge et al., 1999), arguing for the existence of a cell surface protein or proteins that support high-affinity MAG binding. Consistent with this idea, affinity precipitation with immobilized MAG-Fc identified specific protein interactions, some of which are sialic aciddependent (DeBellard and Filbin, 1999; Strenge et al., 1999). Whether this is a reflection of MAG binding to a neuronal sialoglycoprotein or sialoglycoproteins or protein-ganglioside complexes, however, remains unknown. Although several MAG binding proteins have been characterized (Franzen et al., 2001; Strenge et al., 2001), NgR1 is the first binding protein directly shown to be part of a functional MAG receptor complex, yet the observation that MAG binding to $\mathrm{NgR} 1$ is VCN-insensitive and not modulated by the presence of GT1b adds an unexpected twist to the characterization of the neuronal MAG receptor (Domeniconi et al., 2002; Liu et al., 2002).

Because many binding studies probing the lectin activity of MAG were performed on primary neurons, we adopted a neuronal culture system to examine whether NgR1 and/or NgR2 sup- 
ports MAG binding in a sialic acid-dependent manner. We found that in neonatal DRGs the ectopic expression of $\mathrm{NgR} 2$ (and to a lesser extent NgR1) is sufficient to confer high-affinity and sialic acid-dependent MAG binding. Affinity precipitation studies with MAG-Fc, similar to the ones originally used to probe binding partners on neuronal cells (DeBellard and Filbin, 1999; Strenge et al., 1999), showed that MAG binding to NgR1 and NgR2 is VCNsensitive. This contrasts with studies in non-neuronal cells in which NgR1 (Domeniconi et al., 2002; Liu et al., 2002) and NgR2 (K. Venkatesh and R. Giger, unpublished data) support MAG binding in a sialic acid-independent manner. Because NgR1 and NgR2 normally are expressed in neurons, we propose that in a neuronal environment $\mathrm{NgR} 1$ and $\mathrm{NgR} 2$ are part of a high-affinity and sialic acid-dependent MAG recognition complex. Thus our data fit a model in which NgR1 and NgR2 harbor sialic aciddependent as well as sialic acid-independent MAG docking sites. For maximal binding strength both sites are necessary. An important next question concerns the elucidation of the molecular basis of the sialic acid dependence of the MAG-NgR2 and MAG-NgR1 interactions in neurons.

We observed that VCN treatment of neuronally expressed $\mathrm{NgR} 1$ and $\mathrm{NgR} 2$ causes a small but significant drop $(\sim 2-3 \mathrm{kDa})$ in the molecular weight of both receptors. This indicates that both receptors either are highly sialylated glycoproteins $(\sim 10$ terminal sialic acid residues) or alternatively associate with gangliosides in a VCN-sensitive but SDS-resistant manner. Given that $\mathrm{NgR} 1$ occurs as multiple isoelectric variants with a $\mathrm{pI}$ range of 6-8 (our unpublished observation), a large number of terminal sialic acids appear to be unlikely. SDS-resistant interactions of proteins with gangliosides, on the other hand, have been reported, most notably p75 binding to GT1b (Yamashita et al., 2002). Interestingly, the molecular weight of GT1b and other MAG-binding gangliosides is $\sim 2 \mathrm{kDa}$. Because gangliosides support MAG binding in a sialic acid-dependent manner and are necessary for MAG inhibition (Vyas et al., 2002), it is tempting to speculate that in neurons $\mathrm{NgR} 1$ and $\mathrm{NgR} 2$ associate with a specific ganglioside or gangliosides to form a high-affinity MAGbinding complex.

\section{$\mathrm{NgR} 2$ is a neuronal MAG receptor that mediates growth inhibition}

To examine whether NgR2 functions as a neuronal MAG receptor, we expressed NgR2 in neonatal DRGs and P7 CGNs, two cell types that normally do not express NgR2. Ectopic expression of NgR1 or NgR2 in NGF-responsive DRG neurons results in a significant decrease in neurite length on $\mathrm{CHO}-\mathrm{MAG}$, but not on control CHO feeder cells. This suggests that ectopic NgR2, similar to NgR1, functions as a neuronal MAG receptor that mediates growth inhibition. Ectopic NgR1 and NgR2 abolish the growthpromoting effect of MAG on neonatal DRG neurons, resulting in fiber length that is comparable to that observed on control $\mathrm{CHO}$ feeder layers. The relatively modest decrease in fiber length observed in $\mathrm{NgR}_{1}{ }^{+}$and NgR2 ${ }^{+} \mathrm{DRG}$ neurons is somewhat surprising, given the strong inhibitory activity of MAG toward more mature neurons. In light of the fact that neonatal DRG neurons are still neurotrophin-dependent, it is likely that they are in a "primed" state, and thus forced expression of NgR1 or NgR2 may not lead to a robust MAG inhibitory response (Cai et al., 1999). Alternatively, MAG inhibition may be limited because a receptor component or components other than NgR1 or NgR2 are not expressed sufficiently in neonatal DRG. Given that MAGsignaling components are present in embryonic neurons of different origin (Liu et al., 2002; Wong et al., 2002), this, however, appears to be unlikely. Although our studies in DRGs show that ectopic NgR1 and NgR2 lead to a decrease in neurite growth on CHO-MAG cells, we formally cannot distinguish between the following two possibilities: (1) NgR1 and NgR2 are functional MAG receptors that mediate inhibition, and (2) ectopic NgR1 and NgR2 bind MAG unproductively, sequestering it away from a receptor system that normally promotes growth of neonatal DRG neurons; as a result, neurite length is decreased.

Our interpretation that ectopic NgR2 mediates MAG inhibition in neonatal DRG neurons is consistent with the NgR2 gainof-function studies in postnatal CGNs. Forced expression of $\mathrm{NgR} 2$ in CGNs greatly increases the MAG inhibitory response. Together, these findings indicate that NgR2 does not function as a decoy receptor that binds MAG unproductively but, rather, operates as a high-affinity MAG receptor that brings about inhibition.

\section{Structural insights in ligand-receptor interactions}

While this manuscript was in preparation, a study reported that $\mathrm{NgR} 2$ does not support MAG binding, a finding conflicting with our observations (Barton et al., 2003). The main difference between the two studies is that Barton et al. (2003), used soluble AP-MAG, whereas we used MAG-Fc, a bioactive form of MAG, for receptor binding. To compare the two ligands directly, we generated AP-MAG. Consistent with Barton et al. (2003), NgR1, but not NgR2, selectively supports binding of AP-MAG (supplemental Fig. 1, available at www.jneurosci.org as supplemental material). When coupled with our finding that the structural basis of MAG binding is different for NgR1 and NgR2, we propose that AP tagging of MAG sterically interferes with binding to NgR2, but not to NgR1.

\section{$\mathrm{NgR} 2$ and MAG signaling}

Similar to NgR1, NgR2 is linked to the outer leaflet of the neuronal plasma membrane by a GPI anchor. Thus NgR2-mediated MAG inhibition depends on the interaction with additional receptor components, at least one of which is expected to possess a cytoplasmic domain. Obvious signal-transducing candidates for $\mathrm{NgR} 2$ are the pan-neurotrophin receptor p75 (K. C. Wang et al., 2002b; Wong et al., 2002) and Lingo-1 (Mi et al., 2004). Alternatively, binding of NgR2 to NgR1 in cis may lead to an indirect activation of $\mathrm{p} 75 /$ Lingo-1. Our preliminary studies indicate that NgR2 does not associate with p75 in neurons (Chivatakarn et al., 2004), raising the interesting possibility that p75-independent mechanisms exist to bring about MAG inhibition.

Although MAG has received most attention for its role as an inhibitor of axonal regeneration, in steady state the MAG function has been attributed to stabilization of myelin-axon interactions by binding to complementary ligands on the axolemma (Schachner and Bartsch, 2000). Growing evidence suggests that MAG is a bifunctional molecule that, with binding to neuronal cell surface ligands, signals to oligodendrocytes (Umemori et al., 1994; Sun et al., 2004). It will be interesting to explore whether $\mathrm{NgR} 1$ and NgR2, in addition to their function as MAG/myelin receptors, serve as neuronal MAG ligands that contribute to the stability of myelin sheets and their associated axons in vivo.

\section{References}

Barton WA, Liu BP, Tzvetkova D, Jeffrey PD, Fournier AE, Sah D, Cate R, Strittmatter SM, Nikolov DB (2003) Structure and axon outgrowth inhibitor binding of the Nogo-66 receptor and related proteins. EMBO J 22:3291-3302.

Bartsch U, Bandtlow CE, Schnell L, Bartsch S, Spillmann AA, Rubin BP, Hillenbrand R, Montag D, Schwab ME, Schachner M (1995) Lack of 
evidence that myelin-associated glycoprotein is a major inhibitor of axonal regeneration in the CNS. Neuron 15:1375-1381.

Cai D, Shen Y, De Bellard M, Tang S, Filbin MT (1999) Prior exposure to neurotrophins blocks inhibition of axonal regeneration by MAG and myelin via a cAMP-dependent mechanism. Neuron 22:89-101.

Carim-Todd L, Escarceller M, Estivill X, Sumoy L (2003) LRRN6A/LERN1 (leucine-rich repeat neuronal protein 1), a novel gene with enriched expression in limbic system and neocortex. Eur J Neurosci 18:3167-3182.

Chivatakarn O, Venkatesh K, Lee H, Giger RJ (2004) The pan-neurotrophin receptor $\mathrm{p} 75^{\mathrm{NTR}}$ is not necessary for MAG inhibition. Soc Neurosci Abstr 30:942.9.

Collins BE, Yang LJ, Mukhopadhyay G, Filbin MT, Kiso M, Hasegawa A, Schnaar RL (1997) Sialic acid specificity of myelin-associated glycoprotein binding. J Biol Chem 272:1248-1255.

Crocker PR, Varki A (2001) Siglecs, sialic acids and innate immunity. Trends Immunol 22:337-342.

DeBellard ME, Filbin MT (1999) Myelin-associated glycoprotein MAG selectively binds several neuronal proteins. J Neurosci Res 56:213-218.

DeBellard ME, Tang S, Mukhopadhyay G, Shen YJ, Filbin MT (1996) Myelin-associated glycoprotein inhibits axonal regeneration from a variety of neurons via interaction with a sialoglycoprotein. Mol Cell Neurosci 7:89-101.

Domeniconi M, Cao Z, Spencer T, Sivasankaran R, Wang K, Nikulina E, Kimura N, Cai H, Deng K, Gao Y, He Z, Filbin M (2002) Myelinassociated glycoprotein interacts with the Nogo-66 receptor to inhibit neurite outgrowth. Neuron 35:283-290.

Filbin MT (2003) Myelin-associated inhibitors of axonal regeneration in the adult mammalian CNS. Nat Rev Neurosci 4:703-713.

Fournier AE, GrandPre T, Strittmatter SM (2001) Identification of a receptor mediating Nogo-66 inhibition of axonal regeneration. Nature 409:341-346.

Fournier AE, Gould GC, Liu BP, Strittmatter SM (2002) Truncated soluble Nogo receptor binds Nogo-66 and blocks inhibition of axon growth by myelin. J Neurosci 22:8876-8883.

Franzen R, Tanner SL, Dashiell SM, Rottkamp CA, Hammer JA, Quarles RH (2001) Microtubule-associated protein 1B: a neuronal binding partner for myelin-associated glycoprotein. J Cell Biol 155:893-898.

Giger RJ, Wolfer DP, De Wit GM, Verhaagen J (1996) Anatomy of rat semaphorin III/collapsin-1 mRNA expression and relationship to developing nerve tracts during neuroembryogenesis. J Comp Neurol 375:378-392.

Giger RJ, Ziegler U, Hermens WT, Kunz B, Kunz S, Sonderegger P (1997) Adenovirus-mediated gene transfer in neurons: construction and characterization of a vector for heterologous expression of the axonal cell adhesion molecule axonin-1. J Neurosci Methods 71:99-111.

Giger RJ, Urquhart ER, Gillespie SKH, Levengood DV, Ginty DD, Kolodkin AL (1998) Neuropilin-2 is a receptor for semaphorin IV: insight into the structural basis of receptor function and specificity. Neuron 21:1079-1092.

Guirland C, Suzuki S, Kojima M, Lu B, Zheng JQ (2004) Lipid rafts mediate chemotropic guidance of nerve growth cones. Neuron 42:51-62.

Hasegawa Y, Fujitani M, Hata K, Tohyama M, Yamagishi S, Yamashita T (2004) Promotion of axon regeneration by myelin-associated glycoprotein and Nogo through divergent signals downstream of $\mathrm{G}_{\mathrm{i}} / \mathrm{G}$. J Neurosci 24:6826-6832.

Hatten ME (1985) Neuronal regulation of astroglial morphology and proliferation in vitro. J Cell Biol 100:384-396.

Johnson PW, Abramow-Newerly W, Seilheimer B, Sadoul R, Tropak MB, Arquint M, Dunn RJ, Schachner M, Roder JC (1989) Recombinant myelin-associated glycoprotein confers neural adhesion and neurite outgrowth function. Neuron 3:377-385.

Kelm S, Pelz A, Schauer R, Filbin MT, Tang S, de Bellard ME, Schnaar RL, Mahoney JA, Hartnell A, Bradfield P, Crocker PR (1994) Sialoadhesin, myelin-associated glycoprotein, and CD22 define a new family of sialic acid-dependent adhesion molecules of the immunoglobulin superfamily. Curr Biol 4:965-972.

Klinger M, Taylor JS, Oertle T, Schwab ME, Stuermer CA, Diekmann H (2003) Identification of Nogo-66 receptor (NgR) and homologous genes in fish. Mol Biol Evol 21:76-85.

Kolodkin AL, Levengood DV, Rowe EG, Tai YT, Giger RJ, Ginty DD (1997) Neuropilin is a semaphorin III receptor. Cell 90:753-762.

Lauren J, Airaksinen MS, Saarma M, Timmusk T (2003) Two novel mam- malian Nogo receptor homologs differentially expressed in the central and peripheral nervous systems. Mol Cell Neurosci 24:581-594.

Li W, Walus L, Rabacchi SA, Jirik A, Chang E, Schauer J, Zheng BH, Benedetti NJ, Liu BP, Choi E, Worley D, Silvian L, Mo W, Mullen C, Yang W, Strittmatter SM, Sah DW, Pepinsky B, Lee DH (2004) A neutralizing anti-Nogo66 receptor monoclonal antibody reverses inhibition of neurite outgrowth by central nervous system myelin. J Biol Chem 279:43780-43788.

Liu BP, Fournier A, GrandPre T, Strittmatter SM (2002) Myelin-associated glycoprotein as a functional ligand for the Nogo-66 receptor. Science 297:1190-1193.

Maasho K, Marusina A, Reynolds NM, Coligan JE, Borrego F (2004) Efficient gene transfer into the human natural killer cell line, NKL, using the Amaxa nucleofection system. J Immunol Methods 284:133-140.

McGee AW, Strittmatter SM (2003) The Nogo-66 receptor: focusing myelin inhibition of axon regeneration. Trends Neurosci 26:193-198.

McKerracher L, David S, Jackson DL, Kottis V, Dunn RJ, Braun PE (1994) Identification of myelin-associated glycoprotein as a major myelinderived inhibitor of neurite growth. Neuron 13:805-811.

Mi S, Lee X, Shao Z, Thill G, Ji B, Relton J, Levesque M, Allaire N, Perrin S, Sands B, Crowell T, Cate RL, McCoy JM, Pepinsky RB (2004) LINGO-1 is a component of the Nogo-66 receptor/p75 signaling complex. Nat Neurosci 7:221-228.

Mukhopadhyay G, Doherty P, Walsh FS, Crocker PR, Filbin MT (1994) A novel role for myelin-associated glycoprotein as an inhibitor of axonal regeneration. Neuron 13:757-767.

Niederost B, Oertle T, Fritsche J, McKinney RA, Bandtlow CE (2002) Nogo-A and myelin-associated glycoprotein mediate neurite growth inhibition by antagonistic regulation of RhoA and Racl. J Neurosci 22:10368-10376.

Norton WT, Poduslo SE (1973) Myelination in rat brain: method of myelin isolation. J Neurochem 21:749-757.

Oertle T, van der Haar ME, Bandtlow CE, Robeva A, Burfeind P, Buss A, Huber AB, Simonen M, Schnell L, Brösamle C, Kaupmann K, Vallon R, Schwab ME (2003) Nogo-A inhibits neurite outgrowth and cell spreading with three discrete regions. J Neurosci 23:5393-5406.

Pignot V, Hein AE, Barske C, Wiessner C, Walmsley AR, Kaupmann K, Mayeur H, Sommer B, Mir AK, Frentzel S (2003) Characterization of two novel proteins, $\mathrm{NgRH} 1$ and $\mathrm{NgRH} 2$, structurally and biochemically homologous to the Nogo-66 receptor. J Neurochem 85:717-728.

Popkov M, Mage RG, Alexander CB, Thundivalappil S, Barbas 3rd CF, Rader C (2003) Rabbit immune repertoires as sources for therapeutic monoclonal antibodies: the impact of kappa allotype-correlated variation in cysteine content on antibody libraries selected by phage display. J Mol Biol 325:325-335.

Schachner M, Bartsch U (2000) Multiple functions of the myelin-associated glycoprotein MAG (Siglec-4a) in formation and maintenance of myelin. Glia 29:154-165.

Schafer M, Fruttiger M, Montag D, Schachner M, Martini R (1996) Disruption of the gene for the myelin-associated glycoprotein improves axonal regrowth along myelin in C57BL/Wlds mice. Neuron 16:1107-1113.

Schwab ME, Kapfhammer JP, Bandtlow CE (1993) Inhibitors of neurite growth. Annu Rev Neurosci 16:565-595.

Shen YJ, DeBellard ME, Salzer JL, Roder J, Filbin MT (1998) Myelinassociated glycoprotein in myelin and expressed by Schwann cells inhibits axonal regeneration and branching. Mol Cell Neurosci 12:79-91.

Sicotte M, Tsatas O, Jeong SY, Cai CQ, He Z, David S (2003) Immunization with myelin or recombinant Nogo-66/MAG in alum promotes axon regeneration and sprouting after corticospinal tract lesions in the spinal cord. Mol Cell Neurosci 23:251-263.

Song XY, Zhong JH, Wang X, Zhou XF (2004) Suppression of p75NTR does not promote regeneration of injured spinal cord in mice. J Neurosci 24:542-546.

Strenge K, Schauer R, Kelm S (1999) Binding partners for the myelinassociated glycoprotein of N2A neuroblastoma cells. FEBS Lett 444:59-64.

Strenge K, Brossmer R, Ihrig P, Schauer R, Kelm S (2001) Fibronectin is a binding partner for the myelin-associated glycoprotein (Siglec-4a). FEBS Lett 499:262-267.

Sun J, Shaper NL, Itonori S, Heffer-Lauc M, Sheikh KA, Schnaar RL (2004) Myelin-associated glycoprotein (Siglec-4) expression is progressively and 
selectively decreased in the brains of mice lacking complex gangliosides. Glycobiology 14:851-857.

Tang S, Shen YJ, DeBellard ME, Mukhopadhyay G, Salzer JL, Crocker PR, Filbin MT (1997) Myelin-associated glycoprotein interacts with neurons via a sialic acid binding site at ARG118 and a distinct neurite inhibition site. J Cell Biol 138:1355-1366.

Trapp BD, Andrews SB, Cootauco C, Quarles R (1989) The myelinassociated glycoprotein is enriched in multivesicular bodies and periaxonal membranes of actively myelinating oligodendrocytes. J Cell Biol 109:2417-2426.

Tsui-Pierchala BA, Encinas M, Milbrandt J, Johnson Jr EM (2002) Lipid rafts in neuronal signaling and function. Trends Neurosci 25:412-417.

Umemori H, Sato S, Yagi T, Aizawa S, Yamamoto T (1994) Initial events of myelination involve Fyn tyrosine kinase signaling. Nature 367:572-576.

Vinson M, Strijbos PJ, Rowles A, Facci L, Moore SE, Simmons DL, Walsh FS (2001) Myelin-associated glycoprotein interacts with ganglioside GT1b. A mechanism for neurite outgrowth inhibition. J Biol Chem 276:20280-20285.

Vinson M, Rausch O, Maycox PR, Prinjha RK, Chapman D, Morrow R, Harper AJ, Dingwall C, Walsh FS, Burbidge SA, Riddell DR (2003) Lipid rafts mediate the interaction between myelin-associated glycoprotein (MAG) on myelin and MAG-receptors on neurons. Mol Cell Neurosci 22:344-352.

Vyas AA, Schnaar RL (2001) Brain gangliosides: functional ligands for myelin stability and the control of nerve regeneration. Biochem J 83:677-682.
Vyas AA, Patel HV, Fromholt SE, Heffer-Lauc M, Vyas KA, Dang J, Schachner M, Schnaar RL (2002) Gangliosides are functional nerve cell ligands for myelin-associated glycoprotein (MAG), an inhibitor of nerve regeneration. Proc Natl Acad Sci USA 99:8412-8417.

Walmsley AR, McCombie G, Neumann U, Marcellin D, Hillenbrand R, Mir AK, Frentzel S (2004) Zinc metalloproteinase-mediated cleavage of the human Nogo-66 receptor. J Cell Sci 117:4591-4602.

Wang KC, Koprivica V, Kim JA, Sivasankaran R, Guo Y, Neve RL, He Z (2002a) Oligodendrocyte-myelin glycoprotein is a Nogo receptor ligand that inhibits neurite outgrowth. Nature 417:941-944.

Wang KC, Kim JA, Sivasankaran R, Segal R, He Z (2002b) p75 interacts with the Nogo receptor as a co-receptor for Nogo, MAG, and OMgp. Nature 420:74-78.

Wang X, Chun S, Treloar H, Vartanian T, Greer CA, Strittmatter SM (2002) Localization of Nogo-A and Nogo-66 receptor proteins at sites of axonmyelin and synaptic contact. J Neurosci 22:5505-5515.

Wong ST, Henley JR, Kanning KC, Huang KH, Bothwell M, Poo MM (2002) A p $75^{\text {NTR }}$ and Nogo receptor complex mediates repulsive signaling by myelin-associated glycoprotein. Nat Neurosci 5:1302-1308.

Yamashita T, Higuchi H, Tohyama M (2002) The p75 receptor transduces the signal from myelin-associated glycoprotein to Rho. J Cell Biol 157:565-570.

Yang LJ, Zeller CB, Shaper NL, Kiso M, Hasegawa A, Shapiro RE, Schnaar RL (1996) Gangliosides are neuronal ligands for myelin-associated glycoprotein. Proc Natl Acad Sci USA 93:814-818. 